\title{
Deciphering the role of Epstein-Barr virus in the pathogenesis of T and NK cell lymphoproliferations
}

\author{
Christopher P Fox ${ }^{1,2}$, Claire Shannon-Lowe ${ }^{1}$ and Martin Rowe ${ }^{1 *}$
}

\begin{abstract}
Epstein-Barr virus (EBV) is a highly successful herpesvirus, colonizing more than $90 \%$ of the adult human population worldwide, although it is also associated with various malignant diseases. Primary infection is usually clinically silent, and subsequent establishment of latency in the memory B lymphocyte compartment allows persistence of the virus in the infected host for life. EBV is so markedly B-lymphotropic when exposed to human lymphocytes in vitro that the association of EBV with rare but distinct types of T and NK cell lymphoproliferations was quite unexpected. Whilst relatively rare, these EBV-associated T and NK lymphoproliferations can be therapeutically challenging and prognosis for the majority of patients is dismal. In this review, we summarize the current knowledge on the role of EBV in the pathogenesis of these tumours, and the implications for treatment.
\end{abstract}

\section{Introduction}

Primary infection with EBV usually occurs via salivary transmission. It is unclear whether the initial infection occurs in epithelial cells or in B cells in mucosal tissues, but it is infection of B cells that enables life-long persistence of the virus as a largely asymptomatic infection [1]. EBV enters resting $B$ cells via the CD21 receptor and MHC-II co-receptor surface molecules [2-4]. In vitro, infection of B cells results in expression of a limited subset of genes which cooperate to induce cell proliferation and transformation into lymphoblastoid cell lines; these genes include six nuclear antigens (EBNA1, EBNA2, EBNA3A, EBNA3B, EBNA3C and EBNA-LP) and three membrane proteins (LMP1, LMP2A and LMP2B) which are expressed together with abundant non-coding RNAs (EBER1 and EBER2) and several micro-RNAs [5]. In vivo, EBV-infected B cells may undergo limited expansion induced by the transformation-associated viral genes, but thereafter the infected B cells revert to a latent state in the circulating memory B cell pool to evade virus-specific immune $\mathrm{T}$ cell responses $[1,6]$. Normal plasmacytoid differentiation of virus-carrying $B$ cells in lymphoid tissues may lead to

\footnotetext{
* Correspondence: m.rowe@bham.ac.uk

${ }^{1}$ University of Birmingham College of Medical and Dental Sciences, School of Cancer Sciences, Edgbaston, Birmingham, B15 2TT, UK

Full list of author information is available at the end of the article
}

reactivation of virus into lytic replication [7], which involves expression of around 80 viral genes and the production of new infectious virions [8]. Released virions may in turn infect epithelial cells in the oropharynx [9-12], facilitating further virus production in differentiating epithelium and release into the oropharynx [13] for horizontal transmission to new hosts.

From this understanding of the normal life cycle of $E B V$, it is possible to envisage how genetic accidents might give rise to EBV-associated malignancies of $B$ cell or epithelial cell origin [1]. What this classical model of the EBV life-cycle does not explain is how EBV-associated diseases of $\mathrm{T}$ or NK cells might arise. Indeed, as mature $\mathrm{T}$ and NK cells do not express CD21 it is unclear how these cells become infected in the first place. However, EBV-carrying $\mathrm{T}$ and NK cells can undoubtedly result in severe clinical syndromes.

\section{EBV infection of $\mathrm{T}$ or NK cells in vivo}

EBV is not detected in NK or T cells in the blood of healthy carriers, but may be detected at extremely low frequency in tonsillar NK or T cells [14], notably in some patients with infectious mononucleosis (IM), a self-limiting clinical manifestation of primary EBV infection [1]. Infection of NK or T cells is probably an inefficient and rare event, consistent with the lack of CD21 expression on these cells. Nevertheless, a number of 
EBV-associated NK and T lymphoproliferations have been identified, and are now recognised to comprise a heterogeneous spectrum of diseases, affecting humans through all stages of life and conferring considerable morbidity and mortality. The fundamental unifying feature of such illnesses appears to be the clonal expansion of EBV-infected T or NK cells, although the specific viral and host factors initiating and potentiating the disease processes remain largely unresolved. Furthermore it remains quite unclear why infection of similar or identical cell types is associated with such a diverse spectrum of clinical illnesses, occurring both in previously EBVnaive and ostensibly EBV-immune individuals. The clinical, pathological and biological features of the individual diseases are detailed below.

\section{Chronic Active EBV}

In 1948, Isaacs described a cohort of patients with fatigue, fever, splenomegaly and small volume lymphadenopathy persisting for 3 months to over 4 years after an initial episode of clinically-defined IM [15]. A subsequent study of acute IM patients noted that although most patients had an unremarkable clinical course, a subset of patients experienced protracted symptomatology over periods of 4 to 28 months; these patients tended to have unusually high and persistent titres of antibodies to EBV capsid antigen (VCA) and a delayed antibody responses to early antigen (EA) [16].

There are now numerous reports of patients with clinical syndromes consistent with 'chronic symptomatic EBV infection', although terminological inconsistencies have caused some confusion. The term chronic active Epstein-Barr virus (CAEBV) disease describes patients with a systemic EBV-positive lymphoproliferative disease characterised by fever, lymphadenopathy and splenomegaly developing after primary EBV infection in patients without known immunodeficiency [17]. Suggested diagnostic guidelines required persistence of symptoms for at least 6 months associated with high IgG antibody titres to VCA and EA. Absent or low titres of antibodies to EBV nuclear antigen-1 (EBNA1) are also characteristic of patients with chronic symptoms following proven IM $[17,18]$. This definition [17] arose from observations on affected children from the Western hemisphere and was proposed to result from progressive EBV infection of B cells, although this was not formally proven.

\section{Infection of T and NK cells in CAEBV}

The first evidence of an association of CAEBV with infection of non-B cells arose from a detailed clinicopathological study of a young child with clinical and serological evidence of CAEBV [19]. $\mathrm{EBNA}^{+}$cells were detected in blood, bone marrow and lymph node and, unexpectedly, clonal EBV genomes were identified in peripheral blood $\mathrm{CD}^{+} \mathrm{T}$ lymphocytes. There followed a series of reports, predominantly from Japan and East Asia, demonstrating the striking pathological feature of EBV-infected T or NK cells in the blood or tissue of affected patients [20-26]. Importantly, Southern blot analysis of viral terminal repeats consistently demonstrated clonal or oligoclonal EBV genomes [20-25], implicating the virus in the early stages of disease pathogenesis.

The application of quantitative PCR for EBV genome load in peripheral blood and tissue biopsies [27] has provided a more sensitive diagnostic parameter than EBV serology data, which can be normal in a minority of patients with clear clinicopathological evidence of CAEBV [25]. CAEBV patients assessed prior to therapy have viral load values in the order of $10^{3}-10^{7}$ genomes/ $10^{6}$ PBMC $[25,28]$ and $10^{2}-10^{6}$ copies per $\mathrm{ml}$ of plasma [29-31]. There is evidence to suggest that disease severity correlates with higher viral loads [25].

Interestingly, a very recent study of CAEBV cases in US patients (of predominantly non-Asian descent) found that, in contrast to the East Asian data, B cells were the major target of EBV, with clonality demonstrable in all cases. Cases with $\mathrm{T}$ and NK disease did occur, albeit less frequently [32]. Reliable estimates of the incidence of CAEBV cannot be made from existing published data, but the indications are that it is rare in East Asia and even rarer in the West [33].

\section{Clinical features, prognosis and therapy for CAEBV}

A detailed Japanese study of 30 CAEBV cases [25], followed by a nationwide survey that captured data on 82 patients in the period 1990-2001 [28], included elevated EBV DNA load in blood or tissue as a diagnostic criterion alongside the increasingly recognised clinical features, including: fever, hepatitis, lymphadenopathy, hepatosplenomegaly, pancytopenia, uveitis, interstitial pneumonia, hydroa vacciniforme [34], or hypersensitivity to mosquito bites [22]. Interestingly, patients in these analyses could be delineated into two groups according to whether $\mathrm{T}$ cells or NK cells were the predominant EBV-harbouring cell, and each respective group appeared to exhibit different clinical features and prognosis. $T$ cell-type infection was characterised by fever and high titres of EBV-specific antibodies, whereas patients with NK cell-type infection exhibited hypersensitivity to mosquito bites and high titres of IgE as distinguishing features. Patients with $\mathrm{T}$ cell-type infection appeared to have significantly poorer outcomes $[25,28,35]$. For the whole study group of $82 \mathrm{CAEBV}$ patients, predominantly children, overall survival was $58 \%$ at 10 years [28].

The optimal treatment for CAEBV remains unclear but given the generally poor outcomes following 
immunoregulatory drugs and antiviral agents, a new therapeutic approach comprising sequential immunomodulation, cytotoxic chemotherapy and allogeneic hematopoietic SCT (allo-HSCT) has been studied [36]. In a small cohort of 18 patients receiving such a protocol, the 3 -year overall survival was $95.0 \%$. Importantly, a plateau in the survival curve is evident, suggesting the potential of allo-HSCT to achieve long-term disease-free survival for patients with severe CAEBV.

The recent retrospective US study described similar clinical features, albeit in an older cohort (mean age 19 years) and comparable survival data, with no apparent difference in outcome between those with T or NK disease and B cell CAEBV cases. Allo-HSCT appeared to provide a curative option for some patients, sometimes in the context of refractory disease [32].

\section{EBV-associated Haemophagocytic Lymphohistiocytosis}

The earliest description of a distinct clinical syndrome associated with histological evidence of erythrophagocytosis (see Figure 1) was reported in 1939 by two Oxford Pathologists [37]. A detailed description of four fatal cases, termed 'histiocytic medullary histiocytosis' was summarised as follows. "These cases illustrate what we have come to regard as the typical clinical course of the disease: fever, wasting and generalised lymphadenopathy are associated with splenic and hepatic enlargement and in the final stages jaundice, purpura and anaemia with profound leukopenia may occur. Post mortem examination shows a systematised hyperplasia of histiocytes actively engaged in phagocytosis of erythrocytes". These prescient observations remain central features of internationally agreed diagnostic criteria of the present-day

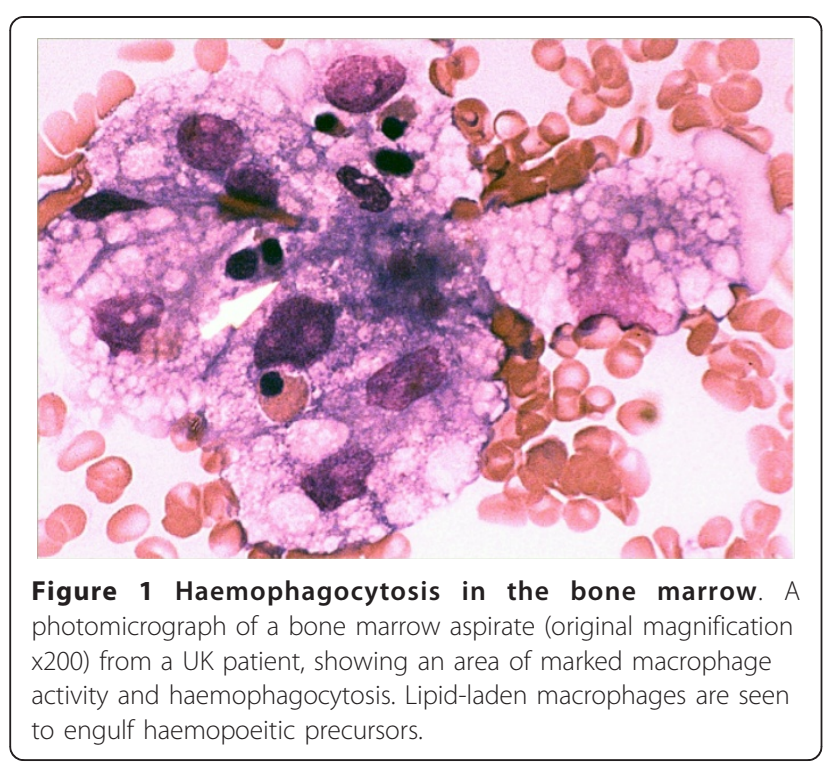

clinicopathological syndrome now termed Haemophagocytic Lymphohistiocytosis (HLH) [38].

Similar clinicopathological entities have been reported under various terminologies, including familial haemophagocytic reticulosis [39], familial erythrophagocytic lymphohisticytosis [40], histiocytic medullary reticulosis [41] and malignant histiocytosis [42]. These reports included seemingly inherited syndromes and some attributable to, or associated with, malignancy. One Japanese survey estimated that the incidence of HLH was less than 1 case/million population/year [43], although the diagnostic challenges and the nature of this study suggest that this may be an underestimate. The incidence of HLH in the Japan is likely to be higher than that in Western countries.

\section{EBV as an aetiological agent of a subset of HLH}

A possible link with viral infection was highlighted from a study of HLH in a group including patients immunosuppressed following renal transplantation [44]. Evidence of active viral infection, predominantly herpesviruses, was obtained in the majority of cases. This entity was termed virus-associated haemophagocytic syndrome (VAHS). Two cases with high IgM titres to $\mathrm{EBV}$, suggested a role for EBV in disease pathogenesis in some cases of HLH [44]. The apparent association with primary EBV infection prompted a detailed analysis of 52 cases of fatal IM in which, following a initially typical presentation of IM, severe pancytopenia developed together with bone marrow evidence of infiltration by lymphoid cells, cellular necrosis and marked histiocytic haemophagocytosis. The median survival time of these patients was six weeks, in whom an Epstein-Barr virus-associated haemophagocytic syndrome was strongly implicated in the cause of death [45]. It is now clear that EBV is the most frequent cause of acquired HLH in the immunocompetent host $[43,46,47]$.

A major breakthrough implicating EBV as a key aetiological agent in HLH, was the identification of viral genomes within $\mathrm{T}$ lymphocytes in tissue biopsies of affected individuals [48-50]. Monoclonality of EBV by Southern blot analyses together with clonal rearrangements of $\mathrm{T}$-cell receptor gene sequences provided evidence of clonal proliferation of a $\mathrm{T}$ cell infected with EBV. This was supported by in situ hybridisation analyses at the single-cell level, showing EBER-specific signals exclusively within a CD45RO ${ }^{+} \mathrm{TCR} \beta^{+}$population; importantly, EBERs were not detectable in B cells or macrophages [51]. Notably, some reports indicated that $\mathrm{EBV}^{+} \mathrm{T}$ cell lymphoma could arise from or coexist with HLH [48], although clear delineation between the two entities is not always straightforward [52-54]. 
The majority of published data have confirmed that $\mathrm{CD}^{+} \mathrm{T}$ cells, most often the $\mathrm{CD}^{+}$subset, both in tissue biopsies [21,49,51,52,55-57] and circulating lymphocytes $[26,58]$, are the dominant infected population in EBV-HLH. However, unequivocal infection of NK cells has also been observed, and may even be the dominant infected cell type in some patients [59].

\section{Epidemiology and risk factors for $\mathrm{HLH}$}

The majority of cases of EBV-HLH occur in the context of primary infection $[45,49,50,60]$ in children and adolescents [61-63]. Adult cases of HLH are rare and are more frequently attributable to malignancy, particularly lymphoma $[43,64]$. In common with other entities within the spectrum of $\mathrm{EBV}^{+} \mathrm{T}$ and NK lymphoproliferations, the literature is dominated by a majority of EBV-HLH cases reported by study groups in East Asia [62]. However, instances in patients of European [49,58], Middle Eastern [54], North American and Hispanic [52] ethnicities have been described. Notwithstanding the fact that inherited immunodeficiencies [65-69] strongly predispose to $\mathrm{HLH}$, and that the original description of VAHS arose in a largely immunocompromised patient group [44], most patients presenting with EBV-HLH have no clinical history of immunodeficiency.

\section{Pathophysiology of HLH}

An in vivo model of HLH [70] described the emergence of erythrocyte and platelet antibodies at the time of peak viral load. This appearance of antibody-coated erythrocytes anteceded erythrophagocytosis in tissues and heralded the onset of the full clinical syndrome. This phagocytosis was shown to be specifically mediated by Fc-mediated macrophage activation and results in the observed cytopenias.

The clinical manifestations of HLH are, at least in part, a result of a dramatically dysregulated inflammatory response due to release of pro-inflammatory cytokines including IFN- $\gamma$, TNF- $\alpha$, IL-6, IL-10 and M-CSF [71]. These mediators are secreted by activated T-lymphocytes and infiltrating histiocytes, which can instigate tissue necrosis and organ dysfunction. Inflammatory cytokines are also responsible for the haematological and biochemical manifestations such as cytopenias, coagulopathy and elevated triglycerides [65]. Serum Fas ligand (a membrane protein expressed by cytotoxic $\mathrm{T}$ and NK cells) has also been noted to be elevated in patients with HLH [72] and may explain features such as liver dysfunction.

Impairment of the cytotoxic function of $\mathrm{NK}$ and $\mathrm{T}$ cells seems to be a common denominator across both inherited and acquired HLH syndromes [47,73], although the mechanisms leading to cytolytic defects in immunocompetent patients with EBV-HLH are not clear. Elevated levels of cytokines such as IL-12 have been shown to impact on NK function [74]. The apparent geographical disparities in the incidence of EBVHLH may suggest a hitherto unidentified genetic susceptibility resulting in a dysfunctional immune response to infected cells.

\section{Prognosis and therapy of EBV-HLH}

The aims of therapy are to suppress the augmented inflammatory response with immunosuppressive/immunomodulatory agents, support and restore organ function, and eliminate EBV-harbouring cells with cytotoxic drugs [75-81]. The best clinical evidence has followed from studies based on the international HLH-94 protocol $[38,82,83]$, incorporating etoposide, dexamethasone and Cyclosporin A [82]. In the case of refractory disease [63], or those with familial defects [84], allo-HSCT can result in long-term disease-free survival.

An analysis of 78 children with EBV-HLH treated with an etoposide-based regimen showed $75.6 \%$ of patients were alive and well after a median follow-up of 4 years, indicating the effectiveness of similar immuno-chemotherapy protocols as used for familial disease [38,82]. The prognosis and outcome of adult patients with EBVHLH has been less well studied. The available published data $[52,54,64,85]$ suggest a more adverse prognosis for adults than children with EBV-HLH, although a higher incidence of co-existing lymphoma in adults, and lack of treatment uniformity may confound these data.

\section{Extra-nodal NK/T-cell lymphoma, nasal type}

Extra-nodal NK/T-cell lymphoma (ENKTL) is a relatively recently characterised clinicopathological entity, being formally incorporated into the WHO classification of haematopoietic and lymphoid tumours in 1999 [86]. However, this entity was probably recognised over a century earlier in 1897 by McBride, who described a patient in whom an ulcer developed on the left lateral surface of the nose that within a year, at the time of death, had extended to both cheeks causing extensive tissue damage to the nose and upper lip [87]. A subsequent report in 1921 [88] described two patients with destructive nasal lesions, in whom syphilis was excluded as a diagnosis and no infectious organism could be identified. Further clinical and histological accounts of such a disease accumulated over the following decades [89-95]. Various terminologies for ENKTL have been used, including: lethal midline granuloma, rhinitis gangrenosa progressiva, polymorphic reticulosis, and malignant midline reticulosis.

\section{Phenotype and genotype of ENKTL}

A study by Ishii et al was the first to demonstrate that the malignant cells in ENKTL reacted with anti-sera 
directed to $\mathrm{T}$ cell, but not B cell, antigens [96]. A separate analysis found evidence of rearranged $\mathrm{T}$ cell receptor (TCR) genes in ENKTL tissue indicative of a clonal $\mathrm{T}$-cell proliferation [97]. The apparent $\mathrm{T}$-cell origin of this lymphoma was corroborated by further pathological studies in East Asia [98,99] and the United States [100]. However, the development of antibodies against the CD56 antigen questioned the $\mathrm{T}$ cell phenotype of the malignant cells [101-104]. It is now recognised that the majority of ENKTL tumours are of NK cell origin, with germline $\mathrm{T}$ cell receptor gene configurations [102,105-110]. The reactivity of polyclonal anti-CD3 antibodies with the cytoplasmic subunit ( $\varepsilon$-chain) of the CD3 molecule in formalin-fixed tissues is the likely explanation for the original phenotypic interpretation [111-114].

The characteristic phenotype of ENKTL is now understood to comprise CD2 ${ }^{+}, \mathrm{CD}_{56}{ }^{+}$, surface $\mathrm{CD}^{-}$(as demonstrated on fresh/frozen tissue) and cytoplasmic $\mathrm{CD} \varepsilon^{+}$(as demonstrated on FFPE tissues). The largest clinicopathological study of ENKTL since its incorporation into the WHO classification [86,115], analysed 136 cases of ENKTL and confirmed the expression of CD56 and cytotoxic markers (TIA-1 and granzyme) in a majority of cases, but also identified a minority of tumours $(14 \%)$ with a $\mathrm{CD}^{+}$phenotype. Rearranged T cell receptor genes were found in approximately onethird of 52 cases tested [116].

\section{Association of ENKTL with EBV}

The first compelling evidence implicating EBV in the development of $\mathrm{T}$ and NK lymphomas arose from a report describing 3 patients with clinical and serological features suggesting pre-existing CAEBV, who subsequently developed fatal $\mathrm{T}$ cell lymphoma containing clonal EBV [117]. Subsequent studies identified EBV genomes and/or EBERs within the tumour cells of both nasal and extra-nasal T and NK lymphomas arising in children and adults [103,107,109,118,119]. The association with EBV was observed to be most robust in extranodal lymphomas and those arising in the nasopharynx [120]. The clonal and episomal form of the virus in the tumour cells [121,122], together with the expression of EBV-encoded transcripts and proteins [21,121-124], suggested a causative role for the virus in disease pathogenesis. The association of ENKTL with EBV is invariable, irrespective of geographical origin [116]. Indeed, demonstration of the virus in the malignant cells is virtually a requisite for diagnosis [115].

\section{Epidemiology and clinical features of ENKTL}

ENKTL is an aggressive malignancy with a unique geographical distribution; rare in Western countries and more frequently encountered in East Asia and Central/
South America [116,125-131]. Robust data are lacking for the incidence of ENKTL as defined by WHO diagnostic criteria, and this is currently being addressed by the ongoing International $\mathrm{T}$ cell project directed by Massimo Federico, Modena, Italy (ClinicalTrials.gov Identifier: NCT00705809). Nevertheless, large epidemiological studies of consecutive NHL cases in China [127] and Korea [126] have shown that whilst mature $\mathrm{T}$ and NK neoplasms (of all subtypes) comprise approximately $30 \%$ NHL, ENKTL accounts for approximately 4-6\% of incident NHL cases. By contrast, the best estimate of incidence in Europe and the United States is that ENKTL represents $4 \%$ of all NK and T cell lymphoma subtypes [116], which equates to approximately $0.5 \%$ of all NHLs [132]. From these data it can be estimated that the incidence of ENKTL may be less than 0.5 cases $/ \mathrm{mil}$ lion population/year in Western countries and in the region of 2-4 cases/million population/year in some Eastern regions.

Patients with ENKTL are usually immunocompetent. The median age of presentation is 45-50 years with a male: female ratio of 2-3:1 [116,126,133-135]. However, it should be emphasised that demographic data on this disease (relating to incidence, age/sex distribution and patient ethnicity) is not well characterised outside East Asia.

ENKTL commonly affects the upper aero-digestive tract (characteristically the nasal cavity), though extranasal disease (e.g. skin, gastrointestinal tract, testis) can account for one quarter of cases [116]. Primary lymph node involvement is rare. Bone marrow involvement at diagnosis, as determined by conventional immunohistochemistry, occurs in a minority (6-14\%) of cases [116,136] although this may be an underestimate [137]. Clinical presentation is typically referable to local symptoms from a nasal mass, including obstructive symptoms and bleeding. Hoarseness of voice, dysphagia, proptosis, ophthalmoplegia and dysphonia can also occur according to the extent of local tumour invasion [138]. Poorer prognosis is conferred by local invasiveness, elevated serum lactate dehydrogenase, advanced stage disease and the presence of B symptoms $[116,136]$.

\section{Therapy for ENKTL}

ENKTL is clinically aggressive, displaying inherent resistance to anthracycline-based chemotherapy regimens such as CHOP [139], adopted empirically from B cell lymphoma studies. The outcome of extra-nasal and advanced stage disease is extremely poor $[116,136,138]$. However, the tumours are usually sensitive to radiation therapy which, when given at relatively high doses [140], is the mainstay of front-line therapy for localised disease [141]. However, in spite of high rates of initial response following involved-field radiotherapy, up to $50 \%$ of those 
with localised disease will experience relapse, usually within a year of completing first-line therapy [138,141-143]. Recently published data from early phase clinical trials examining concurrent chemo-radiotherapy in localised ENKTL $[144,145]$, and chemotherapy combined with L-asparaginase for relapsed/refractory ENKTL are encouraging [146-149], but remain to be tested in randomised phase III clinical studies. Nevertheless, despite signs of therapeutic progress, an extremely poor outcome is anticipated for the majority of patients with this disease. Data from the international $\mathrm{T}$ cell project study [116], showed a median overall survival of 7.8 months for patients with ENKTL, representing the poorest survival of all $\mathrm{T}$ cell lymphoma subtypes examined [150].

Attempts to improve outcome in ENKTL have included studies of high-dose chemotherapy (HDT) with autologous stem cell transplantation (ASCT), primarily undertaken in East Asia. The majority of published data are based on retrospective analyses of relatively small cohorts [151-153]. A pooled analysis of 47 patients from 3 studies suggested a survival advantage for those undergoing ASCT, although the survival benefit appeared small and larger collaborative studies are necessary to demonstrate unequivocal benefit for this approach.

The notion of harnessing a graft-versus-lymphoma effect against malignancies inherently resistant to conventional therapies is attractive and clearly has a role for some patients with more common subtypes of $\mathrm{T}$ cell lymphomas [154,155]. The invariable presence of EBV in the tumour cells of ENKTL, expressing the viral antigens EBNA1, LMP1 and LMP2, provides additional alloreactive $\mathrm{T}$ cell targets. Moreover, initial in vivo studies have adoptively transferred autologous, ex-vivo-stimulated, LMP2-specific cytotoxic T lymphocytes to patients with ENKTL with encouraging results [156,157].

The role of allogeneic HSCT for patients with ENKTL remains unclear. Data from two small series $[153,158]$ (comprising six and twenty-two patients) suggest that a proportion of patients with relapsed and refractory disease can achieve long-term disease-free survival, presumably mediated through a graft-versus lymphoma effect.

\section{Aggressive NK leukaemia}

The first distinct report of an aggressive NK cell leukaemia (ANKL) in an adult described in a 71 year old white man from the United States [159], although the majority of subsequent reports from East Asia have occurred in younger individuals [160]. A cell line established from the first case retained morphological, immunologic, and functional characteristics of NK cells [159]. Further reports of clinically aggressive leukaemias displaying neither a $B$ nor $T$ cell phenotype $[102,159,161,162]$ suggested that such malignancies can arise from non-T cell large granular lymphocytes, or NK cells. The WHO subsequently recognised this aggressive leukaemia as a distinct clinicopathological entity and ANKL was separately incorporated into the lymphoid tumour classification [86].

\section{Association of EBV with ANKL}

In the initial reports of ANKL, studies for EBV were not always performed, although it is now recognised that > 90\% of ANKL cases harbour clonal, episomal EBV $[23,163,164]$.

\section{Clinical features, prognosis and therapy for ANKL}

ANKL is extremely rare, with approximately 100 published cases worldwide [165]. The disease typically affects young to middle age patients (mean age approximately 40 years), with a slight male predominance. Patients with ANKL are almost always systemically unwell at presentation, usually with a high fever and constitutional symptoms such as sweats and weight loss. A leukaemic picture is invariably found, associated with prominent thrombocytopenia and variable degrees of anaemia and neutropenia [165]. Cytogenetic abnormalities are seen in at least two-thirds of cases and are often complex $[160,165]$.

Most cases of ANKL pursue an inexorable clinical course, typically displaying resistance to cytotoxic therapies. Complications such as coagulopathy, haemophagocytic syndrome and multi-organ failure are not uncommon. In spite of treatment with intensive chemotherapy, mortality from ANKL is virtually inevitable with a median survival of less than 2 months [160,163,166-168]. Even for the minority of patients who experience an initial remission following an anthracycline-based regimen, relapse occurs invariably and attempts to improve outcome by the use of allogeneic bone marrow transplantation [169] have not proved widely successful [168].

\section{Differences between ANKL and ENKTL}

ANKL shares many features with extra-nodal NK/T lymphoma, including: cytological features, an almost identical immunophenotype [108] $\left(\mathrm{CD} 2^{+}, \mathrm{CD} 3 \varepsilon^{+}\right.$and $\mathrm{CD} 56^{+}$) although CD16 is thought to be more frequently expressed on ANKL than ENKTL $[168,170]$, and a lack TCR gene rearrangements $[108,165]$. As with ENKTL, ANKL is also seen with increased incidence in East Asia. In the vast majority of cases, distinct clinical features allow these diseases to be clearly delineated, although some patients with ENKTL may progress to an aggressive, systemic disease akin to ANKL $[171,172]$. However, comparative genomic array studies support 
the notion that ANKL and ENKTL are distinct entities [173].

\section{EBV gene expression in $\mathrm{T}$ and NK lymphoproliferations}

A key element to understanding the possible role of EBV in associated disease is knowledge of the pattern of viral gene expression. As mentioned earlier, EBV is a potent transforming agent for primary B cells in vitro, where the establishment of lymphoblastoid cell lines requires the cooperative functions of several so-called 'latent genes' [1]. The pattern of viral gene expression in LCLs is commonly referred to as 'Latency III' [5,174]. In vivo, Latency III may be observed in some EBV infected tonsillar B cells in acute IM patients $[14,175]$ or in immunoblastic B lymphomas in iatrogenically immunosuppressed patients $[176,177]$. However, EBV-associated malignancies are usually associated with more restricted patterns of viral gene expression (Figure 2), because other cellular genetic changes negate the requirement for full Latency III expression and because expression of viral antigens for initiating or maintaining cellular transformation has to be balanced against the cost of antigen exposure to immune-surveillance mechanisms.

The first EBV malignancy shown to express a more restricted pattern of latent viral gene expression was Burkitt's lymphoma (BL), where the only viral protein to be expressed is EBNA1 [178,179] which is essential for the maintenance of the viral episome in dividing cells [180-182]. These tumours also express the non-coding EBERs [178] and several microRNAs derived from the BART transcripts [183]. This pattern of gene expression is commonly referred to as Latency I (Figure 2). Such a restricted pattern of transformation-associated latent genes is possible in BL as these tumours invariably carry chromosome translocations resulting in deregulated expression of the $c-m y c$ oncogene $[1,184]$. It has been proposed that EBNA1, EBERs and BARTs might cooperate with $c-m y c$ driven proliferation in maintaining the malignant phenotype by contributing anti-apoptotic and immune-modulating functions [184].

A third major type of latency in EBV-associated malignancies is Latency-II, in which LMP1, LMP2A and LMP2B proteins are expressed in addition to the Latency I genes (Figure 2). These membrane proteins are important modulators of cell signalling, conferring strong protection against apoptotic signals $[185,186]$ and blocking terminal differentiation of infected cells [187-190]. Prototypic examples of Latency II tumours are nasopharyngeal carcinoma and Hodgkin's lymphoma [1].

Reverse Transcriptase Polymerase Chain Reaction (RT-PCR) assays for EBV latent transcripts can be very sensitive and, by taking advantage of the fact that all latent protein mRNA are products of spliced primary RNA transcripts [8], can be made highly specific and eliminate the possibility of contamination of the assay with viral DNA. In contrast to immunohistochemistry and in situ hybridisation techniques, RT-PCR assays only provide information at the population level within a sample and heterogeneity within a tumour may therefore be missed. However, as EBNA1 is produced from different promoters with different splice products in Latency I or Latency II (Qp promoter) and Latency III (Cp or Wp promoters), and expression of LMP1/2 can distinguish between Latency II and Latency I, RT-PCR can be a simple and sensitive method for distinguishing the major forms of latency [5]. A caveat, however, is that RT-PCR detects expression in the total population which may contain heterogenous patterns of latency at the single cell level.

It is important to recognise that the Latency I, II, III nomenclature represents just three common snapshots of gene expression over a spectrum ranging from Latency 0 (no EBV antigen expression, as observed in circulating memory $\mathrm{B}$ cells in healthy infected

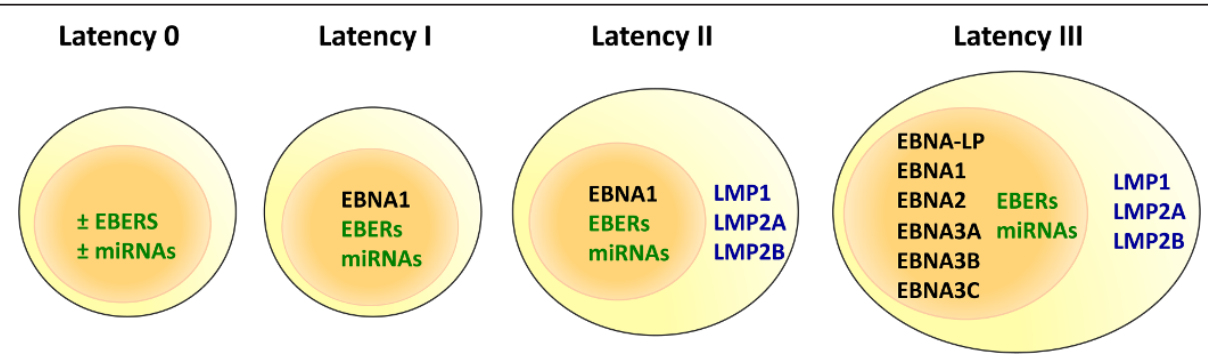

Figure 2 Patterns of latent viral gene expression in EBV-associated tumours. Schematic illustrating major patterns of EBV gene expression observed in different virus:host interactions; non-coding RNAs and micro-RNAs are indicated in green type, nuclear proteins in black type, and membrane proteins in blue type. Latency 0 , sometimes referred to as 'in vivo latency, is the type of latency observed in non-dividing circulating memory B cells of healthy carriers; it is possible that the majority of these cells express no viral genes at all, but that a minority may express non-coding RNAs. Latency I was originally identified in Burkitt' lymphoma, Latency II in nasopharyngeal carcinoma and Hodgkin's lymphoma, and Latency III in post-transplant lymphoproliferative disease. 
individuals), to the Latency III observed in EBV-transformed lymphoblastoid B cell lines. Some tumours may not fall neatly into one of these patterns of latency; for example, LMP1 is often poorly expressed or undetectable in nasopharyngeal carcinomas which otherwise display a Latency II phenotype. Furthermore, immunohistochemical analysis may indicate heterogeneity of expression within a single biopsy, but the pattern of latency is often misleadingly described according the sum total of viral gene products detected.

Against this background, what is known about the pattern of viral gene expression in EBV-associated $\mathrm{T}$ and NK cell diseases?

\section{EBV gene expression in CAEBV}

Analyses of EBV-encoded proteins in cell lines established from patients with CAEBV [191,192], suggest a Latency II pattern of viral gene expression. Studies examining viral gene expression in ex-vivo lymphocytes from CAEBV patients have been scarce. Iwata et al [193] recently described a pattern of EBV latent antigen expression including Qp-initiated EBNA1, LMP1, and LMP2; EBNA2 and lytic transcripts were absent. This pattern is indicative of Latency II. Although this study used RNA extracted from total PBMC, the virus in each case was confirmed to be predominantly within the $\mathrm{T}$ or NK population. These results were consistent with previous, non-quantitative PCR studies on CAEBV PBMC ex-vivo [35,194].

\section{EBV gene expression in HLH}

The pattern of EBV gene expression in EBV-HLH remains unclear. EBERs are frequently expressed [51]. However, whether EBV-HLH lymphoproliferations display a Latency II pattern of viral gene expression, in keeping with the related T or NK disease CAEBV [195] has not been adequately studied. One limited study analysed mRNA from splenic and peripheral blood mononuclear cells in 3 patients with EBV-HLH and found expression of EBERs, Wp/Cp- and Qp-initiated EBNA1, together with EBNA2, LMP1 and LMP2A transcripts [196]. This suggests alternate promoter usage in different cell populations, most likely with a Latency III expression in B cells, which limits interpretation of the data. In another study [59] EBER transcripts were detected in the absence of protein-coding transcripts, which is at odds with the requirement for EBNA1 expression for maintenance of the viral genome in dividing cells. Further studies, preferably including analysis of expression at the single cell level, are required to ascertain the pattern of viral gene expression typically exhibited in EBV-HLH.

\section{EBV gene expression in ENKTL}

Initial analyses of six cases of ENKTL, confirming the presence of the virus within the malignant cells [121], also found numerous LMP1 positive cells by immunohistochemical staining in four of six cases. A more comprehensive follow-up study analysed 23 cases of ENKTL [123]. Immunostaining for LMP1 revealed heterogeneous membrane positivity in a sub-population of EBER ${ }^{+}$cells in 15 of 23 cases. Of note, both cases of extranasal tumours analysed by Chiang et al [123] were LMP1 negative and, importantly, none of the 23 cases expressed EBNA-2 or BZLF1 protein, which is consistent with Latency II or Latency I and no activation of lytic cycle. Further characterisation of RNA transcripts by non-quantitative end-point RT-PCR revealed expression of BARTs (precursor transcripts for BART miRNAs) in the majority of cases, whilst EBNA1 transcripts were detected in 15/23 cases and confirmed to be Qpinitiated. LMP1 transcripts were readily detected in all cases, although LMP2A and LMP2B mRNAs were absent or low in the majority of tumours.

These initial data have been broadly supported by subsequent studies [21,122-124,197-200] suggesting that ENKTL typically express a Latency II pattern of gene expression, although both inter- and intra-tumour heterogeneity exists. In particular, LMP1 expression is variable and heterogeneous at the single cell level in ENKTL [123,200] (Figure 3), whereas LMP2A and LMP2B mRNA levels appear low or absent in analysed cases $[123,197,199]$. Recently, we demonstrated that ENKTL express a hitherto unrecognised LMP2 transcript initiated from within the terminal repeats of the EBV genome [191] that is predicted to encode a protein identical to that from LMP2B transcripts. As the LMP2B protein contains most of the immune $\mathrm{T}$ cell epitope sequences identified to date for LMP2A/B, the LMP2 product identified in ENKTL represents a viable target for adoptive $\mathrm{T}$ cell immunotherapy. Although the viral proteins expressed in ENKTL are not normally immunodominant [1], ongoing work to amplify LMP1and LMP2-specific responses for adoptive transfer have so far produced encouraging results for the treatment of ENKTL $[156,201]$.

\section{EBV gene expression in ANKL}

Due to the rarity of this disease and the often rapidly fatal course, analyses of EBV gene expression in ANKL have been scarce. However, one study from Shanghai found that nine consecutive cases of EBER ${ }^{+}$ANKL were LMP1 negative by immunostaining [165].

\section{Unanswered questions in EBV-associated NK and T lymphoproliferations}

A fundamental unanswered question remains: how does EBV infect NK or T cells? Although experimental infection of primary NK cells and NK cell lines has been reported to be an efficient process [202] these results 


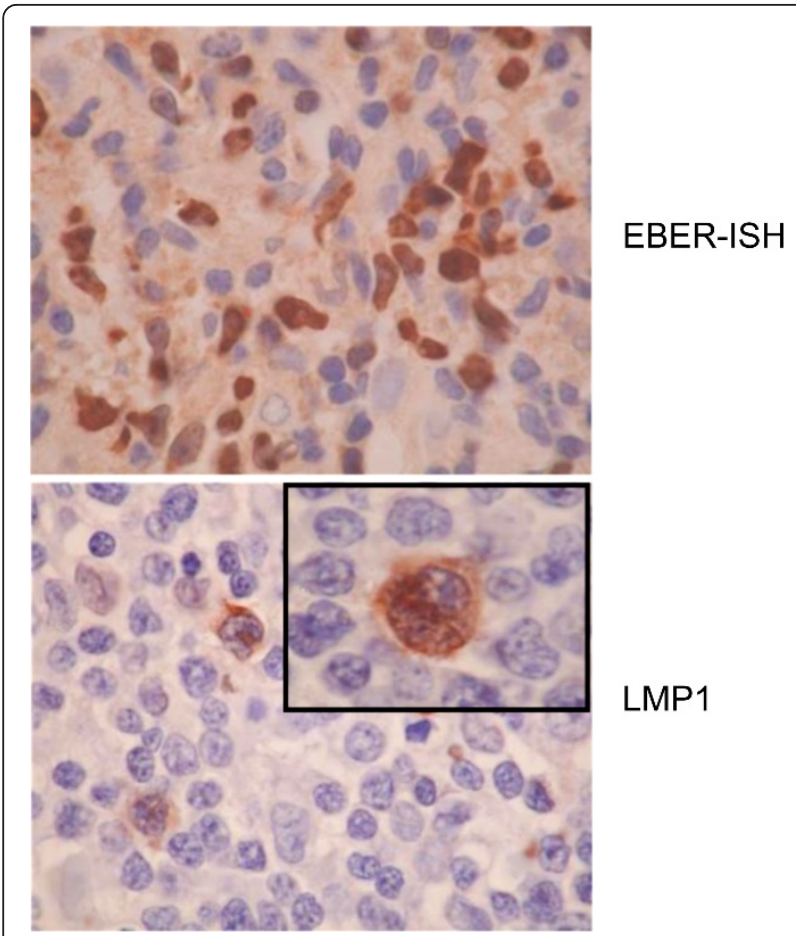

Figure 3 Heterogeneous LMP1 expression within an ENKTL tumour. Upper photomicrograph: EBER in-situ hybridisation on a 4 $\mu \mathrm{m}$ formalin-fixed, paraffin-embedded ENKTL tissue section (optical magnification x200). Courtesy of Dr Simon O'Connor, Department of Histopathology, Nottingham University Hospitals. Lower photomicrograph: Immunohistochemical stain of a $4 \mu \mathrm{m}$ formalinfixed, paraffin-embedded ENKTL tissue section using CS1-4 (antiLMP1) antibodies. The image was captured with a Nikon CoolpixE995 digital camera, via a Nikon Eclipse E400 microscope (optical magnification, $\times 400$ )

have not been replicated in other laboratories. The rarity of observed NK and T cell infections in vivo, would favour the interpretation that infection of these cells is a rare event, but with potentially catastrophic clinical consequences. Whilst the mechanisms of infection in vivo have yet to be elucidated, two attractive possibilities remain to be excluded. The first is via immunological synapses, whereby conjugates between effector T cells or NK cells and virus-harbouring target cells might in rare circumstances facilitate transfer of virus from the target cell to the immune effector cell, akin to that demonstrated for HIV [203,204]. The second mechanism might involve infection of immature precursor cells. It has previously been reported that immature thymocytes transiently express CD21 and can be infected with EBV and whilst the pattern of viral gene expression was not established, EBV was found to synergise with IL-2 to induce proliferation of these cells [205]. Furthermore, as CD $34^{+}, \mathrm{CD} 38^{-}$ stem cells can be differentiated in vitro to transiently express CD21 prior to commitment to T or NK cell lineage (CSL, unpublished observation), this raises the intriguing possibility that infection of a precursor cell has the potential to give rise to either or both NK cells and T cells carrying the same monoclonal EBV episomes. This latter point is relevant to cases of CAEBV and HLH where both cell types may carry EBV in the same patient. Indeed, one recent study on childhood T/NK lymphoproliferations indicated that in some cases the same monoclonal EBV might be present in different cell populations, although no evidence of infection of CD34 ${ }^{+}$stem cells was found [206].

A second question relates to the heterogeneity of EBV gene expression both between patients and within the same lesion, as is seen with LMP1 expression in ENKTL. Heterogeneity within a lesion may represent two different phenotypes of the same parental tumour. Alternatively, it may reflect a dynamic process akin to that reported in EBV-transformed lymphoblastoid B cell lines, where LMP1 levels vary among individual cells such that the difference between the highest and lowest expressing cells may be as great as 100-1000 fold at any given time, but within hours the minimally expressing cells revert to higher levels of LMP1 $[207,208]$. Studies on $\mathrm{EBV}^{+} \mathrm{T}$ and $\mathrm{NK}$ tumour cell lines suggest that LMP1 expression in individual cells within a lesion may be substantially affected by local concentrations of cytokines and by interactions with other cell types $[209,210]$. Heterogeneity between tumours may also be important; the lack of detectable LMP1 in two extranasal ENKTL from one study [123], raises the possibility that additional cellular genetic aberrations may be driving a more malignant tumour phenotype that no longer requires expression of the LMP1 oncogene. In this context it is notable that ANKLs appear not to express LMP1 [165].

Finally, the recent demonstration that ENKTLs express a novel LMP2 transcript, putatively encoding an immuno sub-dominant LMP2B protein, has implications for both the pathogenesis and therapy of these tumours [191]. These tumours represent the first example of EBVinfected cells naturally expressing LMP2B in the absence of LMP2A. This is notable since the N-terminus of LMP2A, which is lacking in LMP2B, is responsible for its major signalling functions. LMP2B acts as a dominantnegative modulator of LMP2A function [211,212]. This dominant-negative property of LMP2B has hitherto been regarded as its major function. However, its expression in the absence of LMP2A in ENKTL tumours highlights the potential of LMP2B to function independently $[212,213]$. As LMP2B is likely to contribute to the initiation or potentiation of EBV-associated NK and T cell diseases, characterisation of the independent functions of LMP2B may identify novel targets for therapy.

\section{Conclusions}

The rarity of EBV-associated NK and T cell malignancies, and the consequent difficulty in obtaining patients 
and tissues for study, has meant that these diseases have been less well-studied compared to their B and epithelial cell counterparts. This is unfortunate since they are clinically challenging and the prognosis for many patients is dismal. The aim of this review was to draw attention to the current state of knowledge of the clinical and virological features of these diseases, and to highlight some unanswered questions regarding the role of EBV in the disease pathogenesis. Deciphering the precise contribution of EBV to these rare T and NK lymphoproliferations will require collaborative, translational efforts to study sufficient numbers of patients and ultimately achieve meaningful therapeutic progress for patients.

\section{List of Abbreviations}

ANKL: Aggressive NK cell leukaemia; CAEBV: Chronic active EBV infection; EA: Early Antigen of EBV; EBER: EBV-encoded RNA; EBNA: EBV-encoded nuclear antigen; EBV: Epstein-Barr virus; ENKTL: Extra-nodal NK-/T-cell lymphoma FFPE: Formalin-fixed paraffin-embeded; HIV: Human immunodeficiency virus; HLH: Haemophagocytic lymphohistiocytosis; HSCT: Haematotopoietic stem cell transplantation; IM: infectious mononucleosis; LMP: EBV-encoded latent membrane protein; NHL: Non-Hodgkin lymphoma; RT-PCR: Reverse transcriptase, Polymerase chain reaction; TCR: T cell receptor; VCA: Viral capsid antigen of EBV; VAHS: virus-associated haemophagocytic syndrome.

\section{Acknowledgements}

The authors are grateful for the funding provided by Leukaemia Lymphoma Research, London (CPF, CSL, MR), Cancer Research UK, London (MR, CSL) and the Gregor Mackay Memorial Fund, a Guys and St Thomas' charity, London (MR, CPF).

\section{Author details}

${ }^{1}$ University of Birmingham College of Medical and Dental Sciences, School of Cancer Sciences, Edgbaston, Birmingham, B15 2TT, UK. ${ }^{2}$ Nottingham University Hospitals, Department of Clinical Haematology, City Hospital campus, Hucknall Road, Nottingham, NG5 1PB, UK.

\section{Authors' contributions}

CPF, MR and CSL conceived and wrote the manuscript. All authors read and approved the final manuscript.

\section{Competing interests}

The authors and funding bodies have no competing interests.

Received: 4 July 2011 Accepted: 7 September 2011

Published: 7 September 2011

\section{References}

1. Rickinson AB, Kieff E: Epstein-Barr virus. In Fields Virology. Volume 2.. 5 edition. Edited by: Knipe DM, Howley PM. Philadelphia: Lippincott, Williams 2007:2655-2700

2. Li Q, Spriggs MK, Kovats S, Turk SM, Comeau MR, Nepom B, HuttFletcher LM: Epstein-Barr virus uses HLA class II as a cofactor for infection of B lymphocytes. J Virol 1997, 71(6):4657-4662.

3. Nemerow GR, Wolfert R, McNaughton MW, Cooper NR: Identification and characterization of the Epstein-Barr virus receptor on human $B$ lymphocytes and its relationship to the C3d complement receptor (CR2). $J$ Virol 1985, 55:347-351.

4. Fingeroth JD, Weis JJ, Tedder TF, Strominger JL, Biro PA, Fearon DT: Epstein-Barr virus receptor of human $B$ lymphocytes is the C3d receptor CR2. Proc Natl Acad Sci USA 1984, 81(14):4510-4514.

5. Rowe M, Kelly GL, Bell Al, Rickinson AB: Burkitt's lymphoma: The Rosetta Stone deciphering Epstein-Barr virus biology. Semin Cancer Biol 2009, 19(6):377-388.
6. Thorley-Lawson D: EBV persistence and latent infection in vivo. In EpsteinBarr Virus. Edited by: Robertson ES. Norfolk: Caister Academic Press; 2005:309-357.

7. Laichalk LL, Thorley-Lawson DA: Terminal differentiation into plasma cells initiates the replicative cycle of epstein-barr virus in vivo. J Virol 2005, 79(2):1296-1307.

8. Kieff E, Rickinson AB: Epstein-Barr virus and its replication. In Fields Virology, 5th Edition. Volume 2.. 5 edition. Edited by: Knipe DM, Howley PM. Philadelphia: Lippincott, Williams 2007:2603-2654.

9. Pegtel DM, Middeldorp J, Thorley-Lawson DA: Epstein-Barr virus infection in ex vivo tonsil epithelial cell cultures of asymptomatic carriers. J Virol 2004, 78(22):12613-12624.

10. Shannon-Lowe C, Rowe M: Epstein-Barr Virus Infection of Polarized Epithelial Cells via the Basolateral Surface by Memory B Cell-Mediated Transfer Infection. PLoS Pathog 2011, 7(5):e1001338.

11. Shannon-Lowe CD, Neuhierl B, Baldwin G, Rickinson AB, Delecluse HJ: Resting $B$ cells as a transfer vehicle for Epstein-Barr virus infection of epithelial cells. Proc Natl Acad Sci USA 2006, 103(18):7065-7070.

12. Tugizov SM, Berline JW, Palefsky JM: Epstein-Barr virus infection of polarized tongue and nasopharyngeal epithelial cells. Nature Medicine 2003, 9:307-314.

13. Hadinoto V, Shapiro M, Sun CC, Thorley-Lawson DA: The dynamics of EBV shedding implicate a central role for epithelial cells in amplifying viral output. PLOS Pathog 2009, 5(7):e1000496.

14. Hudnall SD, Ge Y, Wei L, Yang NP, Wang HQ, Chen T: Distribution and phenotype of Epstein-Barr virus-infected cells in human pharyngeal tonsils. Mod Pathol 2005, 18(4):519-527.

15. Isaacs R: Chronic infectious mononucleosis. Blood 1948, 3(8):858-861.

16. Horwitz CA, Henle W, Henle G, Schmitz H: Clinical evaluation of patients with infectious mononucleosis and development of antibodies to the $\mathrm{R}$ component of the Epstein-Barr virus-induced early antigen complex. Am J Med 1975, 58(3):330-338.

17. Straus SE: The chronic mononucleosis syndrome. J Infect Dis 1988, 157(3):405-412.

18. Henle W, Henle G, Andersson J, Ernberg I, Klein G, Horwitz CA, Marklund G, Rymo L, Wellinder C, Straus SE: Antibody responses to Epstein-Barr virusdetermined nuclear antigen (EBNA)-1 and EBNA-2 in acute and chronic Epstein-Barr virus infection. Proc Natl Acad Sci USA 1987, 84(2):570-574.

19. Kikuta H, Taguchi Y, Tomizawa K, Kojima K, Kawamura N, Ishizaka A, Sakiyama Y, Matsumoto S, Imai S, Kinoshita T, et al: Epstein-Barr virus genome-positive $T$ lymphocytes in a boy with chronic active EBV infection associated with Kawasaki-like disease. Nature 1988, 333(6172):455-457

20. Imai S, Sugiura M, Oikawa O, Koizumi S, Hirao M, Kimura H, Hayashibara $H_{\text {, }}$ Terai N, Tsutsumi H, Oda T, et al: Epstein-Barr virus (EBV)-carrying and -expressing T-cell lines established from severe chronic active EBV infection. Blood 1996, 87(4):1446-1457.

21. Kanegane H, Bhatia K, Gutierrez M, Kaneda H, Wada T, Yachie A, Seki H, Arai T, Kagimoto $S$, Okazaki M, et al: A syndrome of peripheral blood Tcell infection with Epstein-Barr virus (EBV) followed by EBV-positive Tcell lymphoma. Blood 1998, 91(6):2085-2091.

22. Ishihara S, Okada S, Wakiguchi H, Kurashige T, Hirai K, Kawa-Ha K: Clonal lymphoproliferation following chronic active Epstein-Barr virus infection and hypersensitivity to mosquito bites. Am J Hematol 1997, 54(4):276-281.

23. Kawa-Ha K, Ishihara S, Ninomiya T, Yumura-Yagi K, Hara J, Murayama F, Tawa A, Hirai K: CD3-negative lymphoproliferative disease of granular lymphocytes containing Epstein-Barr viral DNA. J Clin Invest 1989, 84(1):51-55.

24. Tsuge I, Morishima T, Morita M, Kimura H, Kuzushima K, Matsuoka H: Characterization of Epstein-Barr virus (EBV)-infected natural killer (NK) cell proliferation in patients with severe mosquito allergy; establishment of an IL-2-dependent NK-like cell line. Clin Exp Immunol 1999, 115(3):385-392.

25. Kimura H, Hoshino Y, Kanegane H, Tsuge I, Okamura T, Kawa K, Morishima T: Clinical and virologic characteristics of chronic active Epstein-Barr virus infection. Blood 2001, 98(2):280-286.

26. Kasahara Y, Yachie A, Takei K, Kanegane C, Okada K, Ohta K, Seki H, Igarashi N, Maruhashi K, Katayama K, et al: Differential cellular targets of Epstein-Barr virus (EBV) infection between acute EBV-associated hemophagocytic lymphohistiocytosis and chronic active EBV infection. Blood 2001, 98(6):1882-1888. 
27. Junying J, Herrmann K, Davies G, Lissauer D, Bell A, Timms J, Reynolds GM, Hubscher SG, Young LS, Niedobitek G, et al: Absence of Epstein-Barr virus DNA in the tumor cells of European hepatocellular carcinoma. Virology 2003, 306(2):236-243.

28. Kimura H, Morishima $T$, Kanegane H, Ohga S, Hoshino $Y$, Maeda A, Imai S, Okano M, Morio T, Yokota S, et al: Prognostic factors for chronic active Epstein-Barr virus infection. J Infect Dis 2003, 187(4):527-533.

29. Yamamoto M, Kimura H, Hironaka T, Hirai K, Hasegawa S, Kuzushima K, Shibata M, Morishima T: Detection and quantification of virus DNA in plasma of patients with Epstein-Barr virus-associated diseases. J Clin Microbiol 1995, 33(7):1765-1768.

30. Kanegane $H$, Wakiguchi $H$, Kanegane C, Kurashige T, Miyawaki T, Tosato G: Increased cell-free viral DNA in fatal cases of chronic active Epstein-Barr virus infection. Clin Infect Dis 1999, 28(4):906-909.

31. Maeda A, Wakiguchi H, Yokoyama W, Hisakawa H, Tomoda T, Kurashige T: Persistently high Epstein-Barr virus (EBV) loads in peripheral blood lymphocytes from patients with chronic active EBV infection. J Infect Dis 1999, 179(4):1012-1015.

32. Cohen Jl, Jaffe ES, Dale JK, Pittaluga S, Heslop HE, Rooney CM, Gottschalk S, Bollard CM, Rao VK, Marques A, et al: Characterization and treatment of chronic active Epstein-Barr virus disease: a 28-year experience in the United States. Blood 2011, 117(22):5835-5849.

33. Cohen Jl, Kimura H, Nakamura S, Ko YH, Jaffe ES: Epstein-Barr virusassociated lymphoproliferative disease in non-immunocompromised hosts: a status report and summary of an international meeting, 8-9 September 2008. Ann Oncol 2009, 20(9):1472-1482.

34. Iwatsuki K, Xu Z, Takata M, Iguchi M, Ohtsuka M, Akiba H, Mitsuhashi Y, Takenoshita $H$, Sugiuchi R, Tagami $H$, et al: The association of latent Epstein-Barr virus infection with hydroa vacciniforme. Br J Dermatol 1999, 140(4):715-721.

35. Kimura H, Hoshino Y, Hara S, Sugaya N, Kawada J, Shibata Y, Kojima S, Nagasaka T, Kuzushima K, Morishima T: Differences between T cell-type and natural killer cell-type chronic active Epstein-Barr virus infection. J Infect Dis 2005, 191(4):531-539.

36. Kawa K, Sawada A, Sato M, Okamura T, Sakata N, Kondo O, Kimoto T, Yamada K, Tokimasa S, Yasui M, et al: Excellent outcome of allogeneic hematopoietic SCT with reduced-intensity conditioning for the treatment of chronic active EBV infection. Bone marrow transplantation 2011, 46(1):77-83.

37. Scott RB, Robb-Smith AHT: Histiocytic Medullary Histiocytosis. Lancet 1939, 234(6047):194-198

38. Henter J, Horne A, Arico M, Egeler RM, Filipovich AH, Imashuku S, Ladisch S, McClain K, Webb D, Winiarski J, et al: HLH-2004: Diagnostic and therapeutic guidelines for hemophagocytic lymphohistiocytosis. Pediatr Blood Cancer 2007, 48(2):124-131.

39. Farquhar JW, Macgregor AR, Richmond J: Familial haemophagocytic reticulosis. Br Med J 1958, 2(5112):1561-1564.

40. Perry MC, Harrison EG Jr, Burgert EO Jr, Gilchrist GS: Familial erythrophagocytic lymphohistocytosis. Report of two cases and clinicopathologic review. Cancer 1976, 38(1):209-218.

41. Kalderon AE: Histiocytic medullary reticulosis associated with cytomegalic inclusion disease. A case report. Cancer 1971, 27(3):659-666.

42. Warnke RA, Kim H, Dorfman RF: Malignant histiocytosis (histiocytic medullary reticulosis). I. Clinicopatholigic study of 29 cases. Cancer 1975, 35(1):215-230.

43. Ishii E, Ohga S, Imashuku S, Yasukawa M, Tsuda H, Miura I, Yamamoto K, Horiuchi H, Takada K, Ohshima K, et al: Nationwide survey of hemophagocytic lymphohistiocytosis in Japan. Int J Hematol 2007, 86(1):58-65.

44. Risdall RJ, McKenna RW, Nesbit ME, Krivit W, Balfour HH Jr, Simmons RL, Brunning RD: Virus-associated hemophagocytic syndrome: a benign histiocytic proliferation distinct from malignant histiocytosis. Cancer 1979, 44(3):993-1002

45. Mroczek EC, Weisenburger DD, Grierson HL, Markin R, Purtilo DT: Fatal infectious mononucleosis and virus-associated hemophagocytic syndrome. Arch Pathol Lab Med 1987, 111(6):530-535.

46. Rouphael NG, Talati NJ, Vaughan C, Cunningham K, Moreira R, Gould C: Infections associated with haemophagocytic syndrome. Lancet Infect Dis 2007, 7(12):814-822.

47. Janka G, Imashuku S, Elinder G, Schneider M, Henter Jl: Infection- and malignancy-associated hemophagocytic syndromes. Secondary hemophagocytic lymphohistiocytosis. Hematol Oncol Clin North Am 1998, 12(2):435-444.

48. Craig FE, Clare CN, Sklar JL, Banks PM: T-cell lymphoma and the virusassociated hemophagocytic syndrome. Am J Clin Pathol 1992, 97(2):189-194

49. Gaillard F, Mechinaud-Lacroix F, Papin S, Moreau A, Mollat C, Fiche M, Peltier S, De Faucal PJ, Rousselet MC, Praloran V, et al: Primary Epstein-Barr virus infection with clonal T-cell lymphoproliferation. Am J Clin Pathol 1992, 98(3):324-333.

50. Kikuta H, Sakiyama Y, Matsumoto S, Oh-Ishi T, Nakano T, Nagashima T, Oka T, Hironaka T, Hirai K: Fatal Epstein-Barr virus-associated hemophagocytic syndrome. Blood 1993, 82(11):3259-3264.

51. Kawaguchi H, Miyashita T, Herbst H, Niedobitek G, Asada M, Tsuchida M Hanada R, Kinoshita A, Sakurai M, Kobayashi N, et al: Epstein-Barr virusinfected T lymphocytes in Epstein-Barr virus-associated hemophagocytic syndrome. J Clin Invest 1993, 92(3):1444-1450.

52. Quintanilla-Martinez L, Kumar S, Fend F, Reyes E, Teruya-Feldstein J, Kingma DW, Sorbara L, Raffeld M, Straus SE, Jaffe ES: Fulminant EBV(+) Tcell lymphoproliferative disorder following acute/chronic EBV infection: a distinct clinicopathologic syndrome. Blood 2000, 96(2):443-451.

53. Imashuku S, Hibi S, Tabata Y, Itoh E, Hashida T, Tsunamoto K, Ishimoto K, Kawano F: Outcome of clonal hemophagocytic lymphohistiocytosis: analysis of 32 cases. Leuk Lymphoma 2000, 37(5-6):577-584.

54. Elazary AS, Wolf DG, Amir G, Avni B, Rund D, Yehuda DB, Sviri S: Severe Epstein-Barr virus-associated hemophagocytic syndrome in six adult patients. J Clin Virol 2007, 40(2):156-159.

55. Chan LC, Srivastava G, Pittaluga S, Kwong YL, Liu HW, Yuen HL: Detection of clonal Epstein-Barr virus in malignant proliferation of peripheral blood CD3+ CD8+ T cells. Leukemia 1992, 6(9):952-956.

56. Mori M, Kurozumi H, Akagi K, Tanaka Y, Imai S, Osato T: Monoclonal proliferation of $\mathrm{T}$ cells containing Epstein-Barr virus in fatal mononucleosis. N Engl J Med 1992, 327(1):58.

57. Noma T, Kou K, Yoshizawa I, Kawano Y, Miyashita T, Mizutani S, Yata J: Monoclonal proliferation of Epstein-Barr virus-infected T-cells in a patient with virus-associated haemophagocytic syndrome. Eur J Pediatr 1994, 153(10):734-738.

58. Beutel K, Gross-Wieltsch U, Wiesel T, Stadt UZ, Janka G, Wagner HJ: Infection of T lymphocytes in Epstein-Barr virus-associated hemophagocytic lymphohistiocytosis in children of non-Asian origin. Pediatr Blood Cancer 2009, 53(2):184-190.

59. Fox CP, Shannon-Lowe C, Gothard P, Kishore B, Neilson J, O'Connor N, Rowe M: Epstein-Barr virus-associated hemophagocytic lymphohistiocytosis in adults characterized by high viral genome load within circulating natural killer cells. Clin Infect Dis 2010, 51(1):66-69.

60. Sullivan JL, Woda BA, Herrod HG, Koh G, Rivara FP, Mulder C: Epstein-Barr virus-associated hemophagocytic syndrome: virological and immunopathological studies. Blood 1985, 65(5):1097-1104.

61. Imashuku S, Hlbi S, Todo S: Hemophagocytic lymphohistiocytosis in infancy and childhood. J Pediatr 1997, 130(3):352-357.

62. Imashuku S: Clinical features and treatment strategies of Epstein-Barr virus-associated hemophagocytic lymphohistiocytosis. Crit Rev Oncol Hematol 2002, 44(3):259-272.

63. Imashuku S, Teramura T, Tauchi H, Ishida Y, Otoh Y, Sawada M, Tanaka H, Watanabe A, Tabata Y, Morimoto A, et al: Longitudinal follow-up of patients with Epstein-Barr virus-associated hemophagocytic lymphohistiocytosis. Haematologica 2004, 89(2):183-188.

64. Takahashi N, Chubachi A, Kume M, Hatano Y, Komatsuda A, Kawabata Y, Yanagiya N, Ichikawa Y, Miura AB, Miura I: A clinical analysis of 52 adult patients with hemophagocytic syndrome: the prognostic significance of the underlying diseases. Int J Hematol 2001, 74(2):209-213.

65. Janka G, Zur Stadt U: Familial and acquired hemophagocytic lymphohistiocytosis. Hematology Am Soc Hematol Educ Program 2005, 82-88.

66. Janka GE: Hemophagocytic syndromes. Blood Rev 2007, 21(5):245-253.

67. Purtilo DT, Cassel CK, Yang JP, Harper R: X-linked recessive progressive combined variable immunodeficiency (Duncan's disease). Lancet 1975, 1(7913):935-940.

68. Sayos J, Wu C, Morra M, Wang N, Zhang X, Allen D, van Schaik S, Notarangelo L, Geha R, Roncarolo MG, et al: The X-linked lymphoproliferative-disease gene product SAP regulates signals induced through the co-receptor SLAM. Nature 1998, 395(6701):462-469. 
69. Coffey AJ, Brooksbank RA, Brandau O, Oohashi T, Howell GR, Bye JM, Cahn AP, Durham J, Heath P, Wray $P$, et al: Host response to EBV infection in X-linked lymphoproliferative disease results from mutations in an SH2-domain encoding gene. Nat Genet 1998, 20(2):129-135.

70. Hsieh WC, Chang Y, Hsu MC, Lan BS, Hsiao GC, Chuang HC, Su IJ: Emergence of anti-red blood cell antibodies triggers red cell phagocytosis by activated macrophages in a rabbit model of EpsteinBarr virus-associated hemophagocytic syndrome. Am J Pathol 2007, 170(5):1629-1639.

71. Henter Jl, Elinder G, Soder O, Hansson M, Andersson B, Andersson U: Hypercytokinemia in familial hemophagocytic lymphohistiocytosis. Blood 1991, 78(11):2918-2922

72. Hasegawa D, Kojima S, Tatsumi E, Hayakawa A, Kosaka Y, Nakamura H, Sako M, Osugi Y, Nagata S, Sano K: Elevation of the serum Fas ligand in patients with hemophagocytic syndrome and Diamond-Blackfan anemia. Blood 1998, 91(8):2793-2799.

73. Henter Jl, Arico M, Elinder G, Imashuku S, Janka G: Familial hemophagocytic lymphohistiocytosis. Primary hemophagocytic lymphohistiocytosis. Hematol Oncol Clin North Am 1998, 12(2):417-433.

74. Poggi A, Costa P, Tomasello E, Moretta L: IL-12-induced up-regulation of NKRP1A expression in human NK cells and consequent NKRP1Amediated down-regulation of NK cell activation. Eur J Immunol 1998, 28(5):1611-1616

75. Ambruso DR, Hays T, Zwartjes WJ, Tubergen DG, Favara BE: Successful treatment of lymphohistiocytic reticulosis with phagocytosis with epipodophyllotoxin VP 16-213. Cancer 1980, 45(10):2516-2520.

76. Henter Jl, Elinder G, Finkel Y, Soder O: Successful induction with chemotherapy including teniposide in familial erythrophagocytic lymphohistiocytosis. Lancet 1986, 2(8520):1402.

77. Fischer A, Virelizier JL, Arenzana-Seisdedos F, Perez N, Nezelof C, Griscelli C: Treatment of four patients with erythrophagocytic lymphohistiocytosis by a combination of epipodophyllotoxin, steroids, intrathecal methotrexate, and cranial irradiation. Pediatrics 1985, 76(2):263-268.

78. Imashuku S, Kuriyama K, Teramura T, Ishii E, Kinugawa N, Kato M, Sako M, Hibi S: Requirement for etoposide in the treatment of Epstein-Barr virusassociated hemophagocytic lymphohistiocytosis. J Clin Oncol 2001, 19(10):2665-2673.

79. Oyama Y, Amano T, Hirakawa S, Hironaka K, Suzuki S, Ota Z: Haemophagocytic syndrome treated with cyclosporin A: a T cell disorder? Br J Haematol 1989, 73(2):276-278

80. Stephan JL, Donadieu J, Ledeist F, Blanche S, Griscelli C, Fischer A: Treatment of familial hemophagocytic lymphohistiocytosis with antithymocyte globulins, steroids, and cyclosporin A. Blood 1993, 82(8):2319-2323

81. Imashuku S, Hibi S, Kuriyama K, Tabata Y, Hashida T, Iwai A, Kato M, Yamashita N, Oda MM, Kinugawa N, et al: Management of severe neutropenia with cyclosporin during initial treatment of Epstein-Barr virus-related hemophagocytic lymphohistiocytosis. Leuk Lymphoma 2000, 36(3-4):339-346

82. Henter J, Samuelsson-Horne A, Arico M, Egeler RM, Elinder G, Filipovich AH, Gadner H, Imashuku S, Komp D, Ladisch S, et al: Treatment of hemophagocytic lymphohistiocytosis with HLH-94 immunochemotherapy and bone marrow transplantation. Blood 2002, 100(7):2367-2373.

83. Imashuku S, Hibi S, Ohara T, Iwai A, Sako M, Kato M, Arakawa H, Sotomatsu M, Kataoka S, Asami K, et al: Effective control of Epstein-Barr virus-related hemophagocytic lymphohistiocytosis with immunochemotherapy. Histiocyte Society. Blood 1999, 93(6):1869-1874.

84. Jabado N, de Graeff-Meeder ER, Cavazzana-Calvo M, Haddad E, Le Deist F, Benkerrou M, Dufourcq R, Caillat S, Blanche S, Fischer A: Treatment of familial hemophagocytic lymphohistiocytosis with bone marrow transplantation from HLA genetically nonidentical donors. Blood 1997 90(12):4743-4748.

85. Imashuku S, Kuriyama K, Sakai R, Nakao Y, Masuda S, Yasuda N, Kawano F, Yakushijin K, Miyagawa A, Nakao T, et al: Treatment of Epstein-Barr virusassociated hemophagocytic lymphohistiocytosis (EBV-HLH) in young adults: a report from the HLH study center. Med Pediatr Oncol 2003, 41(2):103-109.

86. Harris NL, Jaffe ES, Diebold J, Flandrin G, Muller-Hermelink HK, Vardiman J, Lister TA, Bloomfield CD: World Health Organization classification of neoplastic diseases of the hematopoietic and lymphoid tissues: report of the Clinical Advisory Committee meeting-Airlie House, Virginia, November 1997. J Clin Oncol 1999, 17(12):3835-3849.

87. McBride P: Photographs of a case of rapid destruction of the nose and face. Laryng 1897, 12:64-66.

88. Woods R: Observations on malignant granuloma of the nose. British Medical Journal 1921, 2:65.

89. Friedmann I: The pathology of malignant granuloma of the nose. $J$ Laryngol Otol 1955, 69(5):331-341.

90. Spear GS, Walker WG Jr: Lethal midline granuloma (granuloma gangraenescens) at autopsy; report of a case and review of literature. Bull Johns Hopkins Hosp 1956, 99(6):313-332.

91. Lopes De Faria J, Cutin M, Morgante AP, Ferri RG: Malignant granuloma of the face; contribution to its nosology. AMA Arch Otolaryngol 1957, 65(3):255-262

92. Burston $\mathrm{HH}$ : Lethal midline granuloma: is it a pathological entity. Laryngoscope 1959, 69(1):1-43.

93. Eichel BS, Harrison EG Jr, Devine KD, Scanlon PW, Brown HA: Primary lymphoma of the nose including a relationship to lethal midline granuloma. Am J Surg 1966, 112(4):597-605.

94. Eichel BS, Mabery TE: The enigma of the lethal midline granuloma. Laryngoscope 1968, 78(8):1367-1386.

95. Kassel SH, Echevarria RA, Guzzo FP: Midline malignant reticulosis (so-called lethal midline granuloma). Cancer 1969, 23(4):920-935.

96. Ishii Y, Yamanaka N, Ogawa K, Yoshida Y, Takami T, Matsuura A, Isago H, Kataura A, Kikuchi K: Nasal T-cell lymphoma as a type of so-called "lethal midline granuloma". Cancer 1982, 50(11):2336-2344.

97. Gaulard P, Henni T, Marolleau JP, Haioun C, Henni Z, Voisin MC, Divine M, Goossens M, Farcet JP, Reyes F: Lethal midline granuloma (polymorphic reticulosis) and lymphomatoid granulomatosis. Evidence for a monoclonal T-cell lymphoproliferative disorder. Cancer 1988, 62(4):705-710.

98. Yamanaka N, Kataura A, Sambe S, Minase T, Ishii Y: Midfacial T cell lymphoma: characterization by monoclonal antibodies. Ann Otol Rhinol Laryngol 1985, 94(2 Pt 1):207-211.

99. Chan JK, Ng CS, Lau WH, Lo ST: Most nasal/nasopharyngeal lymphomas are peripheral T-cell neoplasms. Am J Surg Pathol 1987, 11(6):418-429.

100. Lippman SM, Grogan TM, Spier CM, Koopmann CF Jr, Gall EP, Shimm DS, Durie BG: Lethal midline granuloma with a novel T-cell phenotype as found in peripheral T-cell lymphoma. Cancer 1987, 59(5):936-939.

101. Ho FC, Choy D, Loke SL, Kung IT, Fu KH, Liang R, Todd D, Khoo RK: Polymorphic reticulosis and conventional lymphomas of the nose and upper aerodigestive tract: a clinicopathologic study of 70 cases, and immunophenotypic studies of 16 cases. Hum Pathol 1990, 21(10):1041-1050.

102. Wong KF, Chan JK, Ng CS, Lee KC, Tsang WY, Cheung MM: CD56 (NKH1)positive hematolymphoid malignancies: an aggressive neoplasm featuring frequent cutaneous/mucosal involvement, cytoplasmic azurophilic granules, and angiocentricity. Hum Pathol 1992, 23(7):798-804

103. Kanavaros P, Lescs MC, Briere J, Divine M, Galateau F, Joab I, Bosq J, Farcet JP, Reyes F, Gaulard P: Nasal T-cell lymphoma: a clinicopathologic entity associated with peculiar phenotype and with Epstein-Barr virus. Blood 1993, 81(10):2688-2695

104. Suzumiya J, Takeshita M, Kimura N, Kikuchi M, Uchida T, Hisano S, Eura Y, Kozuru M, Nomura Y, Tomita $K$, et al: Expression of adult and fetal natural killer cell markers in sinonasal lymphomas. Blood 1994, 83(8):2255-2260.

105. Jaffe ES: Nasal and nasal-type T/NK cell lymphoma: a unique form of lymphoma associated with the Epstein-Barr virus. Histopathology 1995, 27(6):581-583

106. Tao Q, Chiang AK, Srivastava G, Ho FC: TCR-CD56+CD2+ nasal lymphomas with membrane-localized CD3 positivity: are the CD3+ cells neoplastic or reactive? Blood 1995, 85(10):2993-2996.

107. Van Gorp J, De Bruin PC, Sie-Go DM, Van Heerde P, Ossenkoppele GJ, Rademakers LH, Meijer CJ, Van Den Tweel JG: Nasal T-cell lymphoma: a clinicopathological and immunophenotypic analysis of 13 cases. Histopathology 1995, 27(2):139-148.

108. Jaffe ES, Chan JK, Su IJ, Frizzera G, Mori S, Feller AC, Ho FC: Report of the Workshop on Nasal and Related Extranodal Angiocentric T/Natural Killer Cell Lymphomas. Definitions, differential diagnosis, and epidemiology. Am J Surg Pathol 1996, 20(1):103-111.

109. Ho FC, Srivastava G, Loke SL, Fu KH, Leung BP, Liang R, Choy D: Presence of Epstein-Barr virus DNA in nasal lymphomas of $B$ and ' $T$ ' cell type. Hematol Oncol 1990, 8(5):271-281. 
110. Kern WF, Spier CM, Hanneman EH, Miller TP, Matzner M, Grogan TM: Neural cell adhesion molecule-positive peripheral T-cell lymphoma: a rare variant with a propensity for unusual sites of involvement. Blood 1992, 79(9):2432-2437.

111. Chan JK, Tsang WY, Ng CS: Clarification of CD3 immunoreactivity in nasal T/natural killer cell lymphomas: the neoplastic cells are often CD3 epsilon+. Blood 1996, 87(2):839-841.

112. Chan JK, Tsang WY, Pau MY: Discordant CD3 expression in lymphomas when studied on frozen and paraffin sections. Hum Pathol 1995, 26(10):1139-1143.

113. Ohno T, Yamaguchi M, Oka K, Miwa H, Kita K, Shirakawa S: Frequent expression of CD3 epsilon in CD3 (Leu 4)-negative nasal T-cell lymphomas. Leukemia 1995, 9(1):44-52.

114. Strickler JG, Meneses MF, Habermann TM, Ilstrup DM, Earle JD, McDonald TJ, Chang KL, Weiss LM: Polymorphic reticulosis: a reappraisal. Hum Pathol 1994, 25(7):659-665.

115. Chan JKC, Quintanilla-Martinez L, Ferry JA, Peh SC: Extranodal NK/T-cell lymphoma, nasal type. In World Health Organization Classfication of Tumours of Haematopoietic and Lymphoid Tissues.. 4 edition. Edited by: Jaffe ES, Harris NL, Stein H, Vardiman JW. Lyon: IARC Press; 2007:285-288.

116. Au WY, Weisenburger DD, Intragumtornchai T, Nakamura S, Kim WS, Sng I, Vose J, Armitage JO, Liang R: Clinical differences between nasal and extranasal NK/T-cell lymphoma: a study of 136 cases from the International Peripheral T-cell Lymphoma Project. Blood 2008, 113(17):3931-3937.

117. Jones JF, Shurin S, Abramowsky C, Tubbs RR, Sciotto CG, Wahl R, Sands J, Gottman D, Katz BZ, Sklar J: T-cell lymphomas containing Epstein-Barr viral DNA in patients with chronic Epstein-Barr virus infections. N Engl J Med 1988, 318(12):733-741.

118. Su IJ, Lin KH, Chen CJ, Tien HF, Hsieh HC, Lin DT, Chen JY: Epstein-Barr virus-associated peripheral T-cell lymphoma of activated CD8 phenotype. Cancer 1990, 66(12):2557-2562.

119. Harabuchi Y, Yamanaka N, Kataura A, Imai S, Kinoshita T, Mizuno F, Osato T: Epstein-Barr virus in nasal T-cell lymphomas in patients with lethal midline granuloma. Lancet 1990, 335(8682):128-130.

120. Chan JK, Yip TT, Tsang WY, Ng CS, Lau WH, Poon YF, Wong CC, Ma W: Detection of Epstein-Barr viral RNA in malignant lymphomas of the upper aerodigestive tract. Am J Surg Pathol 1994, 18(9):938-946.

121. Tao Q, Ho FC, Loke SL, Srivastava G: Epstein-Barr virus is localized in the tumour cells of nasal lymphomas of NK, T or B cell type. Int J Cancer 1995, 60(3):315-320.

122. Minarovits J, Hu LF, Imai S, Harabuchi Y, Kataura A, Minarovits-Kormuta S, Osato T, Klein G: Clonality, expression and methylation patterns of the Epstein-Barr virus genomes in lethal midline granulomas classified as peripheral angiocentric T cell lymphomas. J Gen Virol 1994, 75(Pt 1):77-84.

123. Chiang AK, Tao Q, Srivastava G, Ho FC: Nasal NK- and T-cell lymphomas share the same type of Epstein-Barr virus latency as nasopharyngeal carcinoma and Hodgkin's disease. Int J Cancer 1996, 68(3):285-290.

124. Kagami $Y$, Nakamura S, Suzuki R, lida S, Yatabe $Y$, Okada Y, Kobayashi T, Tsurumi T, Seto M, Ogura M, et al: Establishment of an IL-2-dependent cell line derived from 'nasal-type' NK/T-cell lymphoma of CD2+, sCD3-, CD3epsilon+, CD56+ phenotype and associated with the Epstein-Barr virus. Br J Haematol 1998, 103(3):669-677.

125. Cho EY, Kim KH, Kim WS, Yoo KH, Koo HH, Ko YH: The spectrum of Epstein-Barr virus-associated lymphoproliferative disease in Korea: incidence of disease entities by age groups. J Korean Med Sci 2008, 23(2):185-192.

126. Yoon SO, Suh C, Lee DH, Chi HS, Park CJ, Jang SS, Shin HR, Park BH, Huh J: Distribution of lymphoid neoplasms in the Republic of Korea: analysis of 5318 cases according to the World Health Organization classification. Am J Hematol 85(10):760-764

127. Au WY, Ma SY, Chim CS, Choy C, Loong F, Lie AK, Lam CC, Leung AY, Tse E, Yau CC, et al: Clinicopathologic features and treatment outcome of mature T-cell and natural killer-cell lymphomas diagnosed according to the World Health Organization classification scheme: a single center experience of 10 years. Ann Oncol 2005, 16(2):206-214.

128. Quintanilla-Martinez L, Franklin JL, Guerrero I, Krenacs L, Naresh KN, RamaRao C, Bhatia K, Raffeld M, Magrath IT: Histological and immunophenotypic profile of nasal NK/T cell lymphomas from Peru: high prevalence of p53 overexpression. Hum Pathol 1999, 30(7):849-855.
129. Arber DA, Weiss LM, Albujar PF, Chen YY, Jaffe ES: Nasal lymphomas in Peru. High incidence of T-cell immunophenotype and Epstein-Barr virus infection. Am J Surg Pathol 1993, 17(4):392-399.

130. Barrionuevo C, Zaharia M, Martinez MT, Taxa L, Misad O, Moscol A, Sarria G, Guerrero I, Casanova L, Flores C, et al: Extranodal NK/T-cell lymphoma, nasal type: study of clinicopathologic and prognosis factors in a series of 78 cases from Peru. Appl Immunohistochem Mol Morphol 2007, 15(1):38-44.

131. van de Rijn M, Bhargava V, Molina-Kirsch $H$, Carlos-Bregni $R$, Warnke RA, Cleary ML, Kamel OW: Extranodal head and neck lymphomas in Guatemala: high frequency of Epstein-Barr virus-associated sinonasal lymphomas. Hum Pathol 1997, 28(7):834-839.

132. Project TN-HsLC: A clinical evaluation of the International Lymphoma Study Group classification of non-Hodgkin's lymphoma. Blood 1997, 89(11):3909-3918.

133. Chim CS, Ma SY, Au WY, Choy C, Lie AK, Liang R, Yau CC, Kwong YL: Primary nasal natural killer cell lymphoma: long-term treatment outcome and relationship with the International Prognostic Index. Blood 2004, 103(1):216-221.

134. Li CC, Tien HF, Tang JL, Yao M, Chen YC, Su IJ, Hsu SM, Hong RL: Treatment outcome and pattern of failure in 77 patients with sinonasal natural killer/T-cell or T-cell lymphoma. Cancer 2004, 100(2):366-375.

135. Pagano L, Gallamini A, Trape G, Fianchi L, Mattei D, Todeschini G, Spadea A, Cinieri S, lannitto $E$, Martelli $M$, et al: NK/T-cell lymphomas 'nasal type': an Italian multicentric retrospective survey. Ann Oncol 2006, 17(5):794-800.

136. Lee J, Suh C, Park YH, Ko YH, Bang SM, Lee JH, Lee DH, Huh J, Oh SY, Kwon HC, et al: Extranodal natural killer T-cell lymphoma, nasal-type: a prognostic model from a retrospective multicenter study. J Clin Oncol 2006, 24(4):612-618.

137. Huang WT, Chang KC, Huang GC, Hsiao JR, Chen HH, Chuang SS, Chen TY, Su WC, Tsao CJ: Bone marrow that is positive for Epstein-Barr virus encoded RNA-1 by in situ hybridization is related with a poor prognosis in patients with extranodal natural killer/T-cell lymphoma, nasal type. Haematologica 2005, 90(8):1063-1069.

138. Liang R: Advances in the management and monitoring of extranodal NK/T-cell lymphoma, nasal type. Br J Haematol 2009, 147(1):13-21.

139. Kim BS, Kim TY, Kim CW, Kim JY, Heo DS, Bang YJ, Kim NK: Therapeutic outcome of extranodal NK/T-cell lymphoma initially treated with chemotherapy-result of chemotherapy in NK/T-cell lymphoma. Acta Oncol 2003, 42(7):779-783.

140. Sakata K, Fuwa N, Kodaira T, Aratani K, Ikeda H, Takagi M, Nishio M, Satoh M, Nakamura S, Satoh H, et al: Analyses of dose-response in radiotherapy for patients with mature T/NK-cell lymphomas according to the WHO classification. Radiother Oncol 2006, 79(2):179-184.

141. Li YX, Yao B, Jin J, Wang WH, Liu YP, Song YW, Wang SL, Liu XF, Zhou LQ, $\mathrm{He} X \mathrm{XH}$, et al: Radiotherapy as primary treatment for stage IE and IIE nasal natural killer/T-cell lymphoma. J Clin Oncol 2006, 24(1):181-189.

142. Cheung MM, Chan JK, Lau WH, Ngan RK, Foo WW: Early stage nasal NK/Tcell lymphoma: clinical outcome, prognostic factors, and the effect of treatment modality. Int J Radiat Oncol Biol Phys 2002, 54(1):182-190.

143. Kim GE, Cho JH, Yang Wl, Chung EJ, Suh CO, Park KR, Hong WP, Park IY, Hahn JS, Roh JK, et al: Angiocentric lymphoma of the head and neck: patterns of systemic failure after radiation treatment. J Clin Oncol 2000, 18(1):54-63.

144. Kim SJ, Kim K, Kim BS, Kim CY, Suh C, Huh J, Lee SW, Kim JS, Cho J, Lee GW, et al: Phase II trial of concurrent radiation and weekly cisplatin followed by VIPD chemotherapy in newly diagnosed, stage IE to IIE, nasal, extranodal NK/T-Cell Lymphoma: Consortium for Improving Survival of Lymphoma study. J Clin Oncol 2009, 27(35):6027-6032.

145. Yamaguchi M, Tobinai K, Oguchi M, Ishizuka N, Kobayashi Y, Isobe Y, Ishizawa K, Maseki N, Itoh K, Usui N, et al: Phase I/II study of concurrent chemoradiotherapy for localized nasal natural killer/T-cell lymphoma: Japan Clinical Oncology Group Study JCOG0211. J Clin Oncol 2009, 27(33):5594-5600.

146. Yamaguchi M, Suzuki R, Kwong YL, Kim WS, Hasegawa Y, Izutsu K, Suzumiya J, Okamura T, Nakamura S, Kawa K, et al: Phase I study of dexamethasone, methotrexate, ifosfamide, L-asparaginase, and etoposide (SMILE) chemotherapy for advanced-stage, relapsed or refractory extranodal natural killer (NK)/T-cell lymphoma and leukemia. Cancer Sci 2008, 99(5):1016-1020. 
147. Jaccard A, Petit B, Girault S, Suarez F, Gressin R, Zini JM, Coiteux V, Larroche C, Devidas A, Thieblemont C, et al: L-asparaginase-based treatment of 15 western patients with extranodal NK/T-cell lymphoma and leukemia and a review of the literature. Ann Oncol 2009, 20(1):110-116.

148. Yong W, Zheng W, Zhu J, Zhang Y, Wang X, Xie Y, Lin N, Xu B, Lu A, Li J: Lasparaginase in the treatment of refractory and relapsed extranodal NK/ T-cell lymphoma, nasal type. Ann Hematol 2009, 88(7):647-652.

149. Jaccard A, Gachard N, Marin B, Rogez S, Audrain M, Suarez F, Tilly H, Morschhauser F, Thieblemont C, Ysebaert L, et al: Efficacy of Lasparaginase with methotrexate and dexamethasone (AspaMetDex regimen) in patients with refractory or relapsing extranodal NK/T-cell lymphoma, a phase 2 study. Blood 2011, 117(6):1834-1839.

150. Vose J, Armitage J, Weisenburger D: International peripheral T-cell and natural killer/T-cell lymphoma study: pathology findings and clinical outcomes. J Clin Oncol 2008, 26(25):4124-4130.

151. Au WY, Lie AK, Liang R, Kwong YL, Yau CC, Cheung MM, Ngan KC, Lau WH, Wong $\mathrm{KH}$, Yiu HY, et al: Autologous stem cell transplantation for nasa NK/T-cell lymphoma: a progress report on its value. Ann Oncol 2003, 14(11):1673-1676.

152. Kim HJ, Bang SM, Lee J, Kwon HC, Suh C, Kim HJ, Lee JH, Ryoo BY, Park YH, Kwon JM, et al: High-dose chemotherapy with autologous stem cell transplantation in extranodal NK/T-cell lymphoma: a retrospective comparison with non-transplantation cases. Bone marrow transplantation 2006, 37(9):819-824.

153. Suzuki R, Suzumiya J, Nakamura S, Kagami Y, Kameoka Jl, Sakai C, Mukai H, Takenaka K, Yoshino T, Tsuzuki T, et al: Hematopoietic stem cell transplantation for natural killer-cell lineage neoplasms. Bone marrow transplantation 2006, 37(4):425-431.

154. Kyriakou C, Canals C, Finke J, Kobbe G, Harousseau JL, Kolb HJ, Novitzky N, Goldstone AH, Sureda A, Schmitz N: Allogeneic stem cell transplantation is able to induce long-term remissions in angioimmunoblastic T-cell lymphoma: a retrospective study from the lymphoma working party of the European group for blood and marrow transplantation. J Clin Oncol 2009, 27(24):3951-3958.

155. Corradini P, Dodero A, Zallio F, Caracciolo D, Casini M, Bregni M, Narni F, Patriarca F, Boccadoro M, Benedetti $F$, et al: Graft-versus-lymphoma effect in relapsed peripheral T-cell non-Hodgkin's lymphomas after reducedintensity conditioning followed by allogeneic transplantation of hematopoietic cells. J Clin Oncol 2004, 22(11):2172-2176.

156. Bollard CM, Gottschalk S, Leen AM, Weiss H, Straathof KC, Carrum G Khalil M, Wu MF, Huls MH, Chang CC, et al: Complete responses of relapsed lymphoma following genetic modification of tumor-antigen presenting cells and T-lymphocyte transfer. Blood 2007, 110(8):2838-2845.

157. Bollard CM, Dotti G, Gottschalk S, Liu E, Sheehan AM, Carrum G, Liu H, Chang C-C, Gee AP, Brenner MK, et al: [293] Administration of TumorSpecific Cytotoxic T Lymphocytes Engineered to Resist TGF-a to Subjects with EBV-Associated Lymphomas. The American Society of Gene \& Cell Therapy Washington DC, USA: Molecular Therapy; 2010.

158. Murashige N, Kami M, Kishi Y, Kim SW, Takeuchi M, Matsue K, Kanda Y, Hirokawa M, Kawabata Y, Matsumura T, et al: Allogeneic haematopoietic stem cell transplantation as a promising treatment for natural killer-cell neoplasms. Br J Haematol 2005, 130(4):561-567.

159. Fernandez LA, Pope B, Lee C, Zayed E: Aggressive natural killer cell leukemia in an adult with establishment of an NK cell line. Blood 1986, 67(4):925-930.

160. Ruskova A, Thula R, Chan G: Aggressive Natural Killer-Cell Leukemia: report of five cases and review of the literature. Leuk Lymphoma 2004, 45(12):2427-2438.

161. Sun T, Brody J, Susin M, Marino J, Teichberg S, Koduru P, Hall WW, Urmacher C, Hajdu SI: Aggressive natural killer cell lymphoma/leukemia. A recently recognized clinicopathologic entity. Am J Surg Pathol 1993, 17(12):1289-1299.

162. Imamura N, Kusunoki Y, Kawa-Ha K, Yumura K, Hara J, Oda K, Abe K,

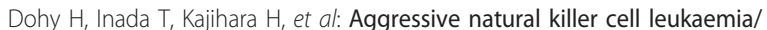
lymphoma: report of four cases and review of the literature. Possible existence of a new clinical entity originating from the third lineage of lymphoid cells. Br J Haematol 1990, 75(1):49-59.

163. Chan JK, Sin VC, Wong KF, Ng CS, Tsang WY, Chan CH, Cheung MM, Lau WH: Nonnasal lymphoma expressing the natural killer cell marker
CD56: a clinicopathologic study of 49 cases of an uncommon aggressive neoplasm. Blood 1997, 89(12):4501-4513.

164. Chan JKC, Jaffe E, Ralfkiaer E, Ko Y-H: Aggressive NK-cell leukaemia. In World Health Organization Classfication of Tumours of Haematopoietic and Lymphoid Tissues.. 4 edition. Edited by: Jaffe ES, Harris NL, Stein H, Vardiman JW. Lyon: IARC Press; 2007:276-277.

165. Ryder J, Wang X, Bao L, Gross SA, Hua F, Irons RD: Aggressive natural killer cell leukemia: report of a Chinese series and review of the literature. Int J Hematol 2007, 85(1):18-25.

166. Song SY, Kim WS, Ko YH, Kim K, Lee MH, Park K: Aggressive natural killer cell leukemia: clinical features and treatment outcome. Haematologica 2002, 87(12):1343-1345

167. Chan JK: Natural killer cell neoplasms. Anat Pathol 1998, 3:77-145.

168. Suzuki R, Suzumiya J, Nakamura S, Aoki S, Notoya A, Ozaki S, Gondo H, Hino N, Mori H, Sugimori H, et al: Aggressive natural killer-cell leukemia revisited: large granular lymphocyte leukemia of cytotoxic NK cells. Leukemia 2004, 18(4):763-770.

169. Teshima T, Miyaji R, Fukuda M, Ohshima K: Bone-marrow transplantation for Epstein-Barr-virus-associated natural killer cell-large granular lymphocyte leukaemia. Lancet 1996, 347(9008):1124.

170. Nava VE, Jaffe ES: The pathology of NK-cell lymphomas and leukemias. Adv Anat Pathol 2005, 12(1):27-34.

171. Jaffe ES: Classification of natural killer (NK) cell and NK-like T-cell malignancies. Blood 1996, 87(4):1207-1210.

172. Soler J, Bordes R, Ortuno F, Montagud M, Martorell J, Pons C, Nomdedeu J, Lopez-Lopez JJ, Prat J, Rutllant M: Aggressive natural killer cell leukaemia/ lymphoma in two patients with lethal midline granuloma. $\mathrm{Br} J$ Haematol 1994, 86(3):659-662.

173. Nakashima Y, Tagawa H, Suzuki R, Karnan S, Karube K, Ohshima K, Muta K, Nawata H, Morishima Y, Nakamura S, et al: Genome-wide array-based comparative genomic hybridization of natural killer cell lymphoma/ leukemia: different genomic alteration patterns of aggressive NK-cell leukemia and extranodal Nk/T-cell lymphoma, nasal type. Genes Chromosomes Cancer 2005, 44(3):247-255.

174. Rowe M, Lear A, Croom-Carter D, Davies AH, Rickinson AB: Three pathways of Epstein-Barr virus (EBV) gene activation from EBNA1-positive latency in B lymphocytes. J Virol 1992, 66(1):122-131.

175. Niedobitek G, Agathanggelou A, Herbst H, Whitehead L, Wright DH, Young LS: Epstein-Barr virus (EBV) infection in infectious mononucleosis: virus latency, replication and phenotype of EBV-infected cells. J Pathol 1997, 182:151-159.

176. Thomas JA, Hotchin NA, Allday MJ, Amlot P, Rose M, Yacoub M, Crawford DH: Immunohistology of Epstein-Barr virus-associated antigens in B cell disorders from immunocompromised individuals. Transplantation 1990, 49:944-953.

177. Young L, Alfieri C, Hennessey K, Evans H, O'Hara C, Anderson KC, Ritz J, Shapiro RS, Rickinson A, Kieff E, et al: Expression of Epstein-Barr virus transformation-associated genes in tissues of patients with EBV lymphoproliferative disease. New Engl J Med 1989, 321:1080-1085.

178. Rowe M, Rowe DT, Gregory CD, Young LS, Farrell PJ, Rupani $H_{1}$ Rickinson AB: Differences in $B$ cell growth phenotype reflect novel patterns of Epstein-Barr virus latent gene expression in Burkitt's lymphoma cells. EMBO J 1987, 6(9):2743-2751

179. Rowe DT, Rowe M, Evan GI, Wallace LE, Farrell PJ, Rickinson AB: Restricted expression of EBV latent genes and T-lymphocyte-detected membrane antigen in Burkitt's lymphoma cells. EMBO J 1986, 5:2599-2607.

180. Rawlins DR, Milman G, Hayward SD, Hayward GS: Sequence-specific DNA binding of the Epstein-Barr virus nuclear antigen (EBNA-1) to clustered sites in the plasmid maintenance region. Cell 1985, 42(3):859-868.

181. Yates JL, Warren N, Sugden B: Stable replication of plasmids derived from Epstein-Barr virus in various mammalian cells. Nature 1985 313(6005):812-815

182. Hochberg D, Middeldorp JM, Catalina M, Sullivan JL, Luzuriaga K, ThorleyLawson DA: Demonstration of the Burkitt's lymphoma Epstein-Barr virus phenotype in dividing latently infected memory cells in vivo. Proc Natl Acad Sci USA 2004, 101(1):239-244.

183. Amoroso R, Fitzsimmons L, Thomas WA, Kelly GL, Rowe M, Bell Al: Quantitative Studies of Epstein-Barr Virus-Encoded MicroRNAs Provide Novel Insights into Their Regulation. J Virol 2011, 85(2):996-1010. 
184. Bornkamm GW: Epstein-Barr virus and its role in the pathogenesis of Burkitt's lymphoma: an unresolved issue. Semin Cancer Biol 2009, 19(6):351-365.

185. Henderson S, Rowe M, Gregory C, Wang F, Kieff E, Rickinson A: Induction of $b c l-2$ expression by Epstein-Barr virus Latent Membrane Protein-1 protects infected B cells from programmed cell death. Cell 1991, 65:1107-1115.

186. Fukuda $\mathrm{M}$, Longnecker R: Latent membrane protein $2 \mathrm{~A}$ inhibits transforming growth factor-beta 1-induced apoptosis through the phosphatidylinositol 3-kinase/Akt pathway. J Virol 2004, 78(4):1697-1705.

187. Dawson CW, Eliopoulos AG, Blake SM, Barker R, Young LS: Identification of functional differences between prototype Epstein-Barr virus-encoded LMP1 and a nasopharyngeal carcinoma-derived LMP1 in human epithelial cells. Virology 2000, 272(1):204-217.

188. Scholle F, Bendt KM, Raab-Traub N: Epstein-Barr virus LMP2A transforms epithelial cells, inhibits cell differentiation, and activates Akt. J Virol 2000, 74(22):10681-10689.

189. Vrzalikova K, Vockerodt M, Leonard S, Bell A, Wei W, Schrader A, Wright KL, Kube D, Rowe M, Woodman CB, et al: Downregulation of BLIMP1-alpha by the EBV oncogene, LMP1, disrupts the plasma cell differentiation program and prevents viral replication in $B$ cells: implications for the pathogenesis of EBV-associated B cell lymphomas. Blood 2011, 117(22):5907-5917.

190. Zheng X, Yuan F, Hu L, Chen F, Klein G, Christensson B: Effect of Blymphocyte- and NPC-derived EBV-LMP1 gene expression on the in vitro growth and differentiation of human epithelial cells. Int/ J Cancer 1994, 57(5):747-753.

191. Fox CP, Haigh TA, Taylor GS, Long HM, Lee SP, Shannon-Lowe C, O'Connor S, Bollard CM, labal J, Chan WC, et al: A novel latent membrane 2 transcript expressed in Epstein-Barr virus-positive NK- and T-cell lymphoproliferative disease encodes a target for cellular immunotherapy. Blood 2010, 116(19):3695-3704.

192. Zhang Y, Nagata H, Ikeuchi T, Mukai H, Oyoshi MK, Demachi A, Morio T, Wakiguchi H, Kimura N, Shimizu N, et al: Common cytological and cytogenetic features of Epstein-Barr virus (EBV)-positive natural killer (NK) cells and cell lines derived from patients with nasal T/NK-cell lymphomas, chronic active EBV infection and hydroa vacciniforme-like eruptions. Br J Haematol 2003, 121(5):805-814.

193. Iwata S, Wada K, Tobita S, Gotoh K, Ito Y, Demachi-Okamura A, Shimizu N, Nishiyama Y, Kimura H: Quantitative analysis of Epstein-Barr virus (EBV)related gene expression in patients with chronic active EBV infection. $J$ Gen Virol 2010, 91(Pt 1):42-50.

194. Yoshioka M, Ishiguro N, Ishiko H, Ma X, Kikuta H, Kobayashi K Heterogeneous, restricted patterns of Epstein-Barr virus (EBV) latent gene expression in patients with chronic active EBV infection. I Gen Virol 2001, 82(Pt 10):2385-2392.

195. Iwata S, Wada K, Tobita S, Gotoh K, Ito Y, Demachi-Okamura A, Shimizu N, Nishiyama Y, Kimura H: Quantitative Analysis of Epstein-Barr Virus (EBV)Related Gene Expression in Patients with Chronic Active EBV Infection. J Gen Virol 2010, 91(Pt.1):42-50.

196. Yoshioka M, Kikuta H, Ishiguro N, Endo R, Kobayashi K: Latency pattern of Epstein-Barr virus and methylation status in Epstein-Barr virus-associated hemophagocytic syndrome. J Med Virol 2003, 70(3):410-419.

197. Kanegane $H$, Wang $F$, Tosato G: Virus-cell interactions in a natural killerlike cell line from a patient with lymphoblastic lymphoma. Blood 1996, 88(12):4667-4675.

198. Xu ZG, Iwatsuki K, Oyama N, Ohtsuka M, Satoh M, Kikuchi S, Akiba H, Kaneko F: The latency pattern of Epstein-Barr virus infection and viral IL10 expression in cutaneous natural killer/T-cell lymphomas. Br J Cancer 2001, 84(7):920-925.

199. van Gorp J, Brink A, Oudejans JJ, van den Brule AJ, van den Tweel JG Jiwa NM, de Bruin PC, Meijer CJ: Expression of Epstein-Barr virus encoded latent genes in nasal T cell lymphomas. J Clin Pathol 1996, 49(1):72-76.

200. Harabuchi Y, Imai S, Wakashima J, Hirao M, Kataura A, Osato T, Kon S: Nasal T-cell lymphoma causally associated with Epstein-Barr virus: clinicopathologic, phenotypic, and genotypic studies. Cancer 1996, 77(10):2137-2149.

201. Bollard CM, Gottschalk S, Sheehan A, Mims M, Carrum G, Liu H, Gee AP, Brenner MK, Rooney CM, Heslop HE: LMP-specific cytotoxic T-lymphocytes administered to EBV+ lymphoma patients after stem cell transplant. Bone Marrow Transpl 2011, 46(EBMT suppl S1):0269.
202. Isobe Y, Sugimoto K, Yang L, Tamayose K, Egashira M, Kaneko T, Takada K, Oshimi K: Epstein-Barr virus infection of human natural killer cell lines and peripheral blood natural killer cells. Cancer Res 2004, 64(6):2167-2174.

203. Igakura T, Stinchcombe JC, Goon PK, Taylor GP, Weber JN, Griffiths GM, Tanaka Y, Osame M, Bangham CR: Spread of HTLV-I between lymphocytes by virus-induced polarization of the cytoskeleton. Science 2003, 299(5613):1713-1716.

204. Jolly C, Sattentau QJ: Retroviral spread by induction of virological synapses. Traffic 2004, 5(9):643-650.

205. Watry D, Hedrick JA, Siervo S, Rhodes G, Lamberti JJ, Lambris JD, Tsoukas CD: Infection of Human Thymocytes by Epstein-Barr Virus. J Exp Med 1991, 173(4):971-980.

206. Ohga S, Ishimura M, Yoshimoto G, Miyamoto T, Takada H, Tanaka T, Ohshima K, Ogawa Y, Imadome K, Abe Y, et al: Clonal origin of EpsteinBarr virus (EBV)-infected T/NK-cell subpopulations in EBV-positive T/NKcell lymphoproliferative disorders of childhood. J Clin Virol 2011, 51(1):31-37.

207. Lam N, Sandberg ML, Sugden B: High physiological levels of LMP1 result in phosphorylation of elF2 alpha in Epstein-Barr virus-infected cells. $J$ Virol 2004, 78(4):1657-1664.

208. Brooks JM, Lee SP, Leese AM, Thomas WA, Rowe M, Rickinson AB: Cyclical expression of EBV latent membrane protein 1 in EBV-transformed $B$ cells underpins heterogeneity of epitope presentation and CD8+ T cell recognition. J Immunol 2009, 182(4):1919-1928.

209. Kis LL, Takahara M, Nagy N, Klein G, Klein E: IL-10 can induce the expression of EBV-encoded latent membrane protein-1 (LMP-1) in the absence of EBNA-2 in B-lymphocytes, in Burkitt lymphoma-, and in NKlymphoma derived cell lines. Blood 2006, 107(7):2928-2935.

210. Ishii H, Takahara M, Nagato T, Kis LL, Nagy N, Kishibe K, Harabuchi Y, Klein E: Monocytes enhance cell proliferation and LMP1 expression of nasal natural killer/T-cell lymphoma cells by cell contact-dependent interaction through membrane-bound IL-15. Int J Cancer 2011.

211. Rechsteiner MP, Berger C, Zauner L, Sigrist JA, Weber M, Longnecker $R$, Bernasconi M, Nadal D: Latent membrane protein $2 B$ regulates susceptibility to induction of lytic Epstein-Barr virus infection. J Virol 2008, 82(4):1739-1747.

212. Shah KM, Stewart SE, Wei W, Woodman CB, O'Neil JD, Dawson CW, Young LS: The EBV-encoded latent membrane proteins, LMP2A and LMP2B, limit the actions of interferon by targeting interferon receptors for degradation. Oncogene 2009, 28(44):3903-3914.

213. Allen MD, Young LS, Dawson CW: The Epstein-Barr Virus-Encoded LMP2A and LMP2B Proteins Promote Epithelial Cell Spreading and Motility. J Virol 2005, 79(3):1789-1802.

doi:10.1186/2042-4280-2-8

Cite this article as: Fox et al:: Deciphering the role of Epstein-Barr virus in the pathogenesis of T and NK cell lymphoproliferations. Herpesviridae 2011 2:8.

\section{Submit your next manuscript to BioMed Central and take full advantage of:}

- Convenient online submission

- Thorough peer review

- No space constraints or color figure charges

- Immediate publication on acceptance

- Inclusion in PubMed, CAS, Scopus and Google Scholar

- Research which is freely available for redistribution

Submit your manuscript at www.biomedcentral.com/submit
C Biomed Central 